THE EFFECTS OF THE AFFORDABLE CARE ACT ON THE NEAR-ELDERLY: EVIDENCE FOR HEALTH INSURANCE COVERAGE AND LABOR MARKET OUTCOMES

\author{
Mark Duggan \\ Gopi Shah Goda \\ Gina Li
}

WORKING PAPER 27936 


\title{
THE EFFECTS OF THE AFFORDABLE CARE ACT ON THE NEAR-ELDERLY: EVIDENCE FOR HEALTH INSURANCE COVERAGE AND LABOR MARKET OUTCOMES
}

\author{
Mark Duggan \\ Gopi Shah Goda \\ Gina Li \\ Working Paper 27936 \\ http://www.nber.org/papers/w27936
NATIONAL BUREAU OF ECONOMIC RESEARCH
1050 Massachusetts Avenue \\ Cambridge, MA 02138 \\ October 2020, Revised November 2020
}

We are especially grateful to Emilie Jackson, whose previous collaboration informed our current work, Anita Mukherjee, participants of the SIEPR-Sloan Working Longer conference, and Robert Moffitt for helpful comments. We thank the Alfred P. Sloan Foundation for generous financial support. The content is solely the responsibility of the authors and not Stanford University or the National Bureau of Economic Research.

NBER working papers are circulated for discussion and comment purposes. They have not been peer-reviewed or been subject to the review by the NBER Board of Directors that accompanies official NBER publications.

(C) 2020 by Mark Duggan, Gopi Shah Goda, and Gina Li. All rights reserved. Short sections of text, not to exceed two paragraphs, may be quoted without explicit permission provided that full credit, including $\left({ }^{\circ}\right.$ notice, is given to the source. 
The Effects of the Affordable Care Act on the Near-Elderly: Evidence for Health Insurance

Coverage and Labor Market Outcomes

Mark Duggan, Gopi Shah Goda, and Gina Li

NBER Working Paper No. 27936

October 2020, Revised November 2020

JEL No. H2,H31,H51,H75,I13,J14,J21,J26

\begin{abstract}
The Affordable Care Act (ACA) not only changed the landscape of health insurance coverage in the United States, but also affected the relationship between working decisions and health insurance. In this paper, we estimate the impact of the ACA on the near-elderly (ages 60-64) in the five years after the implementation of its key provisions in early 2014. We exploit variation across geographic areas in the pre-existing level of uninsurance and use 65-69 year olds, whose insurance coverage was unaffected by the ACA, as a within-region control group. Our findings indicate that the ACA increased health insurance coverage among the near elderly by 4.5 percentage points and reduced their labor force participation rate by 0.6 percentage points.
\end{abstract}

Mark Duggan

Stanford University

Department of Economics

579 Serra Mall

Stanford, CA 94305-6072

and NBER

mgduggan@stanford.edu

Gopi Shah Goda

Stanford University

SIEPR

366 Galvez St.

Stanford, CA 94305

and NBER

gopi@stanford.edu
Gina Li

Stanford University

Department of Economics

579 Jane Stanford Way

Stanford, CA 94305

ginali@stanford.edu 


\section{INTRODUCTION}

The passage of the Affordable Care Act (ACA) in 2010 constituted the largest reform to the U.S. health care system since the 1965 introduction of Medicare and Medicaid. This reform aimed to reduce the fraction of non-elderly individuals uninsured in the U.S., which was around $20 \%$ in the previous decade. The ACA sought to do so through expanding Medicaid for individuals up to $138 \%$ of the federal poverty line, creating incentives for employers to offer insurance coverage, establishing new health care exchanges with subsidies for people with incomes within 100 and 400 percent of the of the federal poverty line, and mandating individual health insurance coverage (though this last provision was later repealed in 2017).

While the ACA greatly expanded access to health insurance, it may also have also weakened the relationship between employment and insurance coverage, thereby affecting labor supply and demand. Indeed, the Congressional Budget Office (CBO) produced a report in 2014 estimating that the ACA would reduce the aggregate hours worked by 1.5 to 2.0 percent between 2017 and 2024, mainly due to a decrease in labor supply. These projections translate into a decrease in the size of the labor force by about 2.0 to 2.5 million by 2024 (CBO 2014). This paper aims to understand how the ACA affected not only the health insurance coverage of the near elderly population, but also whether the higher coverage translated to changes in labor supply.

There are at least three reasons to believe that the Affordable Care Act may have had especially large effects on the near-elderly. First, past evidence has shown that older workers have higher labor supply elasticities (French 2005). Second, because the ACA caps premium contributions based on income, those who face the highest premiums (the near-elderly) receive correspondingly higher subsidies. Figure 1 displays the average effective subsidy faced at different income levels by age in 2015, and shows that older individuals had much higher effective 
subsidies. Finally, the near-elderly generally have higher values of health insurance than younger workers since their average health care spending is significantly higher. Consistent with this and as shown in Figure 2, the highest fraction of families in which annual out-of-pocket spending on health care exceeds $\$ 2,000$ is among those with 55-64 year olds.

In this paper, we evaluate whether the additional health insurance coverage induced by the ACA affected labor market outcomes for the near-elderly. We use individual-level data from the American Community Survey (ACS) for the 2010 through 2018 period. Our analyses exploit geographic variation in the pre-existing uninsurance rates across areas. We also use 65-69 year olds, whose insurance options did not change significantly with the ACA due to their nearuniversal Medicare coverage, as a within-region control group. Our empirical approach is similar to the methodologies of previous work aimed at estimating the effect of Medicare introduction in 1965 (Finkelstein, 2007; Finkelstein and McKnight, 2008) or the 2006 Massachusetts Health Reform (Kolstad and Kowalski, 2012; Miller, 2012) as well as previous work on the ACA (Duggan, Goda, Jackson 2019; Courtemanche et. al 2017). Because our variation stems from differences in pre-ACA uninsurance rates, our methodology may not capture certain labor supply effects of the ACA. For example, to the extent that people with insurance from employers dropped out of the labor force due to the availability of insurance through the ACA, our identification strategy is ill-suited to identify these changes.

Our results illustrate that the ACA substantially altered the insurance coverage among the near elderly. We estimate that an increase in the pre-existing uninsurance rate of 10 percentage points led on average to a post-ACA increase in health insurance coverage of 4.0 percentage points for 60-64 year olds relative to 65-69 year olds. This coverage increase was driven by increases in coverage through employers, direct purchase, and Medicaid, and we also find that the number of 
types of coverage per person increased differentially. When we look at changes that differentiate between Medicaid expansion and non-expansion states, we find evidence that the increase in insurance coverage was significantly greater among expansion states. Furthermore, the composition of changes differed: increases in directly purchased coverage were larger in nonexpansion states, while Medicaid coverage increases were larger in expansion states.

We examine the labor market consequences for those gaining coverage from the ACA by investigating whether there were differential changes in labor market outcomes across areas with varying baseline levels of uninsurance and across age groups using the same research design. Our findings indicate that a 10 percentage point greater pre-ACA uninsurance rate led to a 0.5 percentage point larger reduction in labor force participation among 60-64 year olds. This reduction in labor force participation was driven by statistically significant reductions in both unemployment and self-employment. Employment appears to have fallen as well, though the estimates are statistically significant only in non-expansion states. Putting these results for health insurance and labor force together, our findings indicate that for every additional one hundred 6064 year olds who gained insurance coverage as a result of the ACA, approximately 13 individuals exited the labor force on net.

There is a long and extensive literature analyzing health insurance takeup decisions following U.S. healthcare reforms, such as the Medicaid expansions of the 1980s or 1990s (Currie and Gruber, 1996a; Currie and Gruber, 1996b; Cutler and Gruber, 1996; Aizer and Grogger 2003; Hamersma and Kim 2013) and examining the link between health insurance and labor market decisions (Madrian, 1994; Gruber and Madrian, 2002). Given the scope and magnitude of the ACA reform, a recent and growing literature has also sought to estimate the effect of this policy on individual health insurance and is generally in agreement in substantial coverage increases for the 
overall population (Sommers et. al., 2014, 2015, 2016; Courtemanche et. al 2017; Frean, Gruber, and Sommers, 2017; Duggan, Goda, Jackson, 2019) and in particular, the near elderly (Freed, 2017; Long et. al., 2017).

However, previous studies have failed to find that the ACA induced substantial labor market changes (Gooptu et. al., 2016; Gustman, Steinmeier, and Tabatabai, 2019; Kaestner et. al. 2017; Buchmueller, Levy, and Valleta, 2018; among others). Much less work has focused on the near elderly population close to the age of Medicare eligibility, whose working decisions could be more responsive on average than the non-elderly adult population. Ayyagari (2019) finds that individuals adjust their retirement expectations to retiring earlier due to the ACA. With regards to realized labor supply decisions, with the exception of Wood (2019), who finds a decrease in labor force participation, existing studies find little to no effect of increased retirement behavior (Levy, Buchmueller, and Nikpay, 2018; Gustman, Steinmeier, and Tabatabai, 2019; Aslim, 2019). It is worth noting that all of these studies that look specifically at retirement and find small or null results use either self-reported retirement status (Levy et al. 2018 and Gustman et al. 2019) or an indicator for receiving retirement income in the past 12 months (Aslim 2019). If some who are not working do not yet think of themselves as retired, it is possible that focusing on this narrower outcome could miss some of the effect of the ACA on the labor force for the near elderly. It is also possible that some of these differences are due to the time periods and empirical strategies used.

The main contributions of our study are the focus on the near-elderly and the addition of a within-region control group whose insurance coverage and labor market outcomes would not be expected to change as a result of the ACA. While there is an extensive literature on the effects of the ACA on both insurance coverage and labor market outcomes, existing papers examining labor 
market effects generally focus on exploring whether outcomes changed differentially across Medicaid expansion and non-expansion states. Our approach allows us to flexibly control for changing conditions in labor markets that may be correlated with the pre-existing share of uninsured in a region.

The rest of the paper proceeds as follows. Section II provides details regarding the data we use in the analysis including average characteristics prior to ACA implementation. Section III describes our empirical strategy. We report our results and robustness exercises in Section IV, and Section V concludes.

\section{DATA AND ANALYSIS SAMPLE}

Our main analysis utilizes the American Community Survey (ACS), an annual survey of U.S. households as conducted by the U.S. Census Bureau. They survey a wide variety of household and individual level topics. We focus on detailed data on working decisions, demographics, health insurance coverage, and income sources. The Census mails its survey to approximately 3.5 million addresses in a given year, and follows up with phone or in person visits for those in addresses who have not responded. Due to these efforts, the response rate for the ACS is quite high, typically around 97 percent. We utilize a version of the ACS that is harmonized across years, called IPUMS (Integrated Public Use Microdata Series) by the University of Minnesota.

Our main analysis focuses on a sample of observations from 2010 through 2018 for civilians age 60 to 69 , constituting 3,590,073 person-year observations. We therefore limit to 4 years before the implementation of the ACA in January 2014, and use all years of available data post 2014. The ACS surveys health insurance coverage at the time of the interview, in contrast with the Current Population Survey, which tracks coverage status over the previous calendar year. Insurance coverage falls into seven categories: insurance through an employer, insurance directly 
purchased, Medicare, Medicaid (or other government assisted plan, such as Medical Assistance or plans for those with disabilities or low incomes), Tricare and other military insurance, Veteran's Affairs (VA) coverage, or coverage from the Indian Health Service. Individuals self-report their health insurance status and the type of insurance. Therefore, there is a possibility that there is misreporting and measurement error, due to how individuals might interpret the wording on the questionnaire. The ACS includes a variable for health insurance coverage overall, which includes any of the several types of coverage as listed above, with the exception of insurance through the Indian Health Service (IHS). Note that individuals can also have more than one type of health insurance coverage, and we create a variable that sums the total number of coverages, with the exception of IHS. We also utilize a variety of labor market outcomes, such as employment status in the last week, an indicator for being out of the labor force (defined as not having employment and not searching for a job over the last four weeks), self-employment, and usual hours worked per week over the past 12 months. We use hours and employment status to construct an indicator for working part time, defined as being employed and working less than 30 hours per week. Our analysis variables are summarized for each year in Table 1.

Figure 3 illustrates health insurance coverage prior to the implementation of the ACA in 2014, by age group. The sum total of the percentages exceed 100 percent, because some individuals report coverage from multiple sources. We see that uninsurance rates are higher among younger age groups in the baseline, where the primary source of insurance is through a private employer. The elderly saw almost universal coverage by Medicare, but often supplement this with other sources. Children and young adults also saw higher rates of coverage with insurance through Medicaid, as Medicaid eligibility requirements were more generous for children. 
Our analysis leverages variation in the pre-ACA share of individuals in a geographic area without health insurance coverage. The finest possible level of geography that is available in the public ACS data is a PUMA, or Public Use Microdata Area. PUMAs are delineated so as to not cross state borders and each must have a population of at least 100,000 in the decennial census. Since PUMAs are based on population and not area, places like Los Angeles typically have several PUMAs based on census tract, while PUMAS in rural areas are usually based on counties. PUMAs are redefined every ten years, due to the introduction of a new decennial census. Within our sample time frame, the ACS utilized one set of 2,071 PUMAs for 2010 and 2011 data, while switching to another set of 2,351 PUMAs for 2012 onwards. As a consequence, we utilize IPUM's harmonization of PUMAs. IPUMS has aggregated 2000 and 2010 PUMAs into consistent PUMAs, which by construction have the same boundaries across our 2010 through 2018 analysis period. There are 1,078 consistent PUMAs and no observations are dropped from the data.

We aggregate the individual level data on health insurance coverage for 60-64 year olds at the PUMA level to calculate the baseline levels of uninsurance used in our analysis. Figure 4 shows a "heat map" that illustrates the variation in the baseline levels of uninsurance for this age group. The average value of baseline uninsurance across PUMAs in this near-elderly age group is 11.7 percent, with a standard deviation of 6.0 percent, and the share varies from a low of 1.5 percent to a maximum of 52.7 percent.

We provide the intuition behind our identification strategy in Figure 5, which shows the trajectory of average health insurance coverage by year for four different groups: $60-64$ year olds living in the bottom and top quartile PUMAs ranked by baseline uninsurance among the near elderly, and 65-69 year olds living in the bottom and top quartile PUMAs ranked by these same measures of uninsurance. As shown in the figure, 60-64 year olds living in the top quartile PUMAs 
by baseline uninsurance experienced substantially higher increases in health insurance coverage when the ACA was implemented than did the other three groups.

\section{EMPIRICAL METHODS}

Our empirical approach leverages geographic variation in uninsurance among the near elderly prior to the ACA's implementation, age (due to the fact that the ACA did not change insurance coverage for 65-69 year olds), and time. In some of our specifications, we also examine whether the effects varied for Medicaid expansion states versus non-expansion states. Our baseline regression equation is as follows:

(1) $I N S_{\text {iapt }}=\delta_{0}$ POST $_{t} \times$ Unins $_{p} \times$ Age60 $_{-} 64_{a}+\beta X_{\text {iapt }}+\gamma_{t}+\mu_{a}+\theta_{p}+\alpha_{a t}+\varphi_{p t}+$ $\omega_{a p}+\varepsilon_{\text {iapt }}$

in which $I N S_{\text {iapt }}$ represents an indicator for whether individual $i$ living in PUMA $p$ and age $a$ has any health insurance, private employer-based coverage, directly-purchased coverage, or Medicaid coverage in time $t ; \operatorname{POST}_{t}$ is an indicator equal to 1 in 2014 or later and 0 otherwise, Unins $p$ represents the pre-ACA uninsurance rate among the near elderly for PUMA $p$, and $X_{\text {iapt }}$ includes demographic controls for gender, race, education, and ethnicity. Standard errors are clustered at the PUMA level. The variables $\gamma_{t}, \mu_{a}, \theta_{p}, \alpha_{a t}, \varphi_{p t}$, and $\omega_{a p}$ represent fixed effects and all lowerorder interaction terms. PUMA-by-year fixed effects account for differential trends in the outcomes that could be correlated with baseline levels of uninsurance, year-by-age fixed effects account for differential trends by age, and age-by-PUMA fixed effects account for systematic differences in ages in different locations. Note that because we include these detailed fixed effects, the main effects of $P O S T_{t}$, Unins $_{p}$ and Age60_64 $a$ drop out of the regression. We hypothesize that 
$\delta_{0}$ is positive, that is, insurance coverage grew more rapidly among the near elderly in areas with higher pre-existing uninsurance for 60-64 year olds relative to 65-69 year olds.

States are heterogeneous with respect to Medicaid expansion status, so we extend our

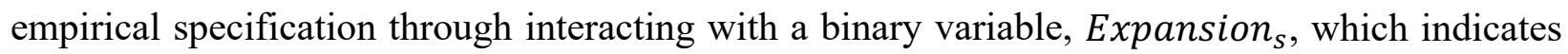
whether the state has expanded its Medicaid program by January 1, 2014. Therefore, we additionally estimate equation (2):

(2) $I_{\text {INS }}$ iapt $=\delta_{1}$ POST $_{t} \times$ Unins $_{p} \times$ Age60_64 $_{a}+\delta_{2}$ POST $_{t} \times$ Unins $_{p} \times$

$$
\text { Age60_64 }{ }_{a} \times \text { Expansion }_{s}+\beta X_{\text {iapt }}+\gamma_{t}+\mu_{a}+\theta_{p}+\alpha_{a t}+\varphi_{p t}+\omega_{a p}+\varepsilon_{\text {iapt }}
$$

As with (1), geographic areas with higher shares of uninsured individuals prior to ACA ought to see greater increases in health insurance coverage, and thus, $\delta_{1}>0$. In addition, it is plausible that the overall level of health insurance increased more due to the ACA in Medicaid expansion states, i.e. $\delta_{2}>0$. In addition, Equation (2) allows the sources of coverage to change differentially for expansion and non-expansion states.

To estimate the effect of the ACA on labor market outcomes, we perform an analogous set of reduced-form regressions as specified in (1) and (2) using labor market outcomes as the dependent variables instead of health insurance coverage. We investigate whether PUMAs with larger ACA-induced increases in health insurance coverage among the near elderly also have larger changes in labor market outcomes for this group. Finally, we perform a subsample analysis to see if the results for both insurance coverage and labor market outcomes vary across observable characteristics such as marital status and age.

The effects of ACA on labor supply is theoretically ambiguous, and we provide a conceptual framework through which we can interpret our empirical estimates, following Duggan, Goda and Jackson (2019). Appendix Table A.1 shows a transition matrix, where rows reflect the 
individual's status prior to the ACA and the columns reflect possible status after the ACA. Because our empirical strategy relies on variation in the share of the near elderly population that was uninsured, the estimates are not designed to reflect any labor market impacts on those already insured prior to the ACA (bottom half of table). These individuals may substitute away from health insurance coverage conditional on employment towards health insurance that can be obtained through other channels and that is no longer conditional on working. Specifically, we interpret our results as shedding light on labor market transitions associated with movements from uninsurance to insurance (top right quadrant of table).

Identification in our empirical strategy relies on the assumption that outcomes in geographic areas with a higher fraction of baseline uninsurance for aged 60-64 would have evolved in a similar manner as in areas with low baseline uninsurance, absent the ACA, after controlling flexibly for changes in area-level insurance coverage and labor market outcomes experienced by 65-69 year olds and person-level demographics. The second specification that allows for heterogeneity by Medicaid expansion status assumes that for a given baseline share uninsured, outcomes in expansion states would have evolved in a similar way to states that did not expand. We emphasize that our analysis does not rule out different levels of insurance coverage or labor market outcomes across areas for reasons other than the ACA that are changing over time, as long as they are common to 65-69 year olds. This strategy would account for differential recovery following the great recession that could be related to the underlying income distribution or the rate of economic growth in an area.

\section{EMPIRICAL RESULTS}

\section{A. Health insurance coverage}


Table 2 displays the results of estimating Equation (1) on outcome variables pertaining to health insurance coverage and its source. All of the specifications include controls for gender, race, ethnicity, education, and all one- and two-way interactions between single year-of-age fixed effects, year fixed effects, and PUMA fixed effects. The outcome variable is listed in the column header. We include the mean of the dependent variable in the bottom row of the table averaged over the pre-ACA years for the 60-64 year old sample.

The results in the table provide evidence that the ACA induced statistically significant increases in health insurance coverage among the near elderly. In Column (1), we see that PUMAs with a higher share of the near-elderly population uninsured had larger increases in health insurance coverage. More specifically, average coverage rates increased by 4.0 percentage points more for 60-64 year olds relative to 65-69 year olds in areas where the baseline uninsurance among the near elderly was 10 percentage points higher. In Columns (2) - (7), we see that the overall increase was driven by increases in Medicaid coverage, directly-purchased health insurance, and employer-based coverage, and there was also an increase in people reporting more than one source of health insurance coverage.

When we interact our triple-difference estimate with Medicaid expansion status (Table 3) we see that coverage increases for 60-64 year olds were more responsive to differences in baseline uninsurance rates in states that expanded Medicaid relative to states that did not. We also see that most of the coverage increases in non-expansion states were driven by directly-purchased insurance and employer coverage, while in expansion states, the coverage increases were primarily driven by Medicaid.

Next, we explore heterogeneous effects by minority status, sex, education level, and marital status, by running our main specifications on subsamples of the population. We maintain the same 
definition of fraction uninsured in the PUMA as before, where the fraction uninsured refers to the overall aged 60-64 population, and not the specific subsample. Tables 4 and 5 illustrate the effect on insurance coverage and show that the relationship between coverage and prior uninsurance levels is larger for minorities and those with a high school degree or less. Furthermore, we see that insurance coverage increased more for expansion states than non-expansion states, across all subsamples and that the stronger relationship for minorities and those with lower levels of education is driven primarily by larger increases in non-expansion states.

\section{B. Labor market outcomes}

We next provide evidence regarding the effect of the ACA-induced increases in health insurance coverage on labor market outcomes in Tables 6 and 7, which display the results of estimating (1) and (2) on the labor market outcomes summarized in Table 1. As in earlier tables, the column heading denotes the dependent variable. Pre-ACA means of the dependent variables are reported in the final rows below the regression results.

Table 6 indicates that 60-64 year olds in regions with a 10 percentage point higher level of uninsurance saw reductions in labor force participation of 0.5 percentage points relative to $65-69$ year olds. This reduction is statistically significant at the 5 percent level, and appears to be driven by reductions in both unemployment and self-employment. We do not detect evidence that employment overall is lower, nor that the fraction of individuals working part-time changed. When we examine the number of hours conditional on working, we also find no evidence of reductions for those most-affected by the ACA's provisions.

When we investigate whether there were differential effects among expansion and nonexpansion states (Table 7), we find that overall, the results were similar in these two sets of states. 
The results in this table further suggest that the reduction in labor force participation is driven by reductions in both unemployment and self-employment. Interpreting these results through the lens of Table A.1 suggests that the changes in labor market outcomes we observe result from transitions from employment or unemployment while uninsured to being out of the labor force with insurance coverage. This could reflect the availability of subsidized health insurance outside of employment inducing those employed at firms that did not offer health insurance to leave the labor force due to an income effect. A reduction in unemployment could a result of previously unemployed and uninsured individuals moving out of the labor force because they stop searching for employment due to subsidized coverage available outside of employment and/or an income effect.

In the aggregate, our point estimates suggest that for every one hundred 60-64 year olds who gained insurance coverage, approximately 13.4 people exited the labor force. ${ }^{1}$ Our point estimates further suggest that approximately 7.1 of these 100 people left self-employment and 6.2 stopped searching for work and therefore exited unemployment.

We perform some "back of the envelope" calculations to gauge the aggregate implications of our findings. Using the age 65-69 group as our control, we can run a simple differences-indifferences model, regressing each individual's insured status on a set of age fixed effects, year fixed effects, and the interaction between an indicator for being in age 60-64 and an indicator for post-2014 (along with the same set of controls). This regression suggests that the 60-64 age group experienced an increase in insured status of 4.52 percentage points relative to 65-69 year olds. In 2013, there were 18.3 million 60-64 year olds, and our results therefore suggest that approximately 826,000 non-elderly individuals acquired insurance as a result of the ACA. Using our labor market estimates from above, we estimate that 110,000 non-elderly individuals left the labor force. This

\footnotetext{
${ }^{1}$ This represents the ratio of the coefficient estimate of -0.0536 in Column 1 of Table 6 and the corresponding estimate of 0.401 in Column 1 of Table 2.
} 
represents a decline of 0.6 percentage points in the near-elderly labor force participation rate, with 58,000 leaving self-employment and 51,000 exiting unemployment. In 2013, there were approximately 10.1 million 60-64 year olds in the labor force, so that our estimates suggest an ACA-induced decline of 1.1 percent in the size of the near-elderly (60-64) labor force.

Tables 8 and 9 examine the effect on labor force participation for subsamples, and these are analogous to Tables 4 and 5 for health insurance. The reductions in labor force participation are more pronounced for those with a high school degree or less, and those who are married. The point estimates suggest that for every one hundred 60-64 year olds with a high school degree or less who acquired health insurance as a result of the ACA, 18.7 left the labor force. ${ }^{2}$ When we include an interaction term for expansion status, we are underpowered to detect significant differences in our subsamples and do not find strong evidence that the effect differs in expansion states, consistent with our full analysis.

In contrast with much of the existing literature, we do find ACA induced reductions in labor force participation. This paper differs in several regards with prior studies. First, we focus specifically on the near elderly, as opposed to the general work age population. For several reasons, as discussed in the introduction, we expect this group to be more elastic and closer to making retirement decisions. Given that the near-elderly are less likely to have child dependents, this is also a group that is traditionally not a target of state Medicaid policies. Therefore, ACA potentially has greater effects for this group both in terms of more generous exchange subsidies and in offering insurance coverage to a previously untargeted population. Second, much of the prior focus has been on the Medicaid expansion, which misses out on the effects of healthcare exchanges. Nationally, $7.3 \%$ of 55-64 year olds are enrolled in exchanges. Meanwhile, exchange enrollment

\footnotetext{
${ }^{2}$ This corresponds to taking the ratio of 0.0907 and 0.485 , the coefficients of column 3 in tables 4 and 8 .
} 
rates are $1.5 \%, 4.1 \%, 4.5 \%$, and $5.4 \%$ for the less than $18,18-34,35-44$, and $45-54$ age groups, respectively in $2017 .^{3}$

One notable exception is Wood (2019), who does find some ACA-induced labor supply reductions when leveraging the Medicaid expansion and magnitude of the potential exchange subsidy using income estimates from the ACS. The methodology relies on estimating potential subsidy based on income, which is prone to measurement error in self-reported income and endogeneity arising out of labor supply changes affecting the subsidy. The author also uses a simulated instrument based on income bands and household type to address this issue; however, the IV strategy assumes that individuals do not exhibit large shifts in income, even though the near elderly is more elastic in their labor supply. Our study complements this analysis by providing an alternative way of incorporating both Medicaid expansion and exchange subsidies, using the 6569 age group as the within-location control group.

\section{Variation by Subsidy Levels}

Our main analysis exploits variation in age and pre-existing levels of uninsurance among the near-elderly. However, there is also considerable variation in the effective level of the premium tax credit across areas. As was mentioned earlier, because the ACA caps premium contributions based on income, those who face the highest premiums receive correspondingly higher subsidies, as highlighted in Figure 1. In addition, individuals who purchase health insurance from exchanges in geographic areas where premiums are high also receive higher subsidies. In this section, we explore whether coverage and labor market outcomes change differentially in areas

\footnotetext{
3 Source: Author's calculations. Population estimates by age group is produced from IPUMS-ACS 2017 (civilians) Exchange enrollment by age and state available from Kaiser Family Foundation's Marketplace Plan Selection by Age, derived from Centers for Medicare and Medicaid Services' Marketplace Open Enrollment Public Use Files.
} 
where subsidy levels are higher. Theoretically, one might expect the introduction of a larger effective subsidy to induce a larger behavioral response, all else equal.

To do this, we must first develop a proxy for the effective subsidy across areas. We obtain premiums by county for the year 2014 from the Kaiser Family Foundation for the second lowest cost silver tier plan, which is the plan that is used to determine the subsidy level. We calculate for each county the subsidy level implied by these premiums for a 60 -year-old in a single member household with modified adjusted gross income of $133 \%$ FPL. Because our ACS data lacks county identifiers but has identifiers for consistent PUMAs, we first use the Missouri Census Data Center's Geocorr's (Geographic Correspondence Engine) crosswalk from counties to 2012 PUMAs. We use this crosswalk to calculate the average subsidy by 2012 PUMAs, which is the average subsidy of all counties that overlap with the 2012 PUMA definition, weighted by the fraction of the 2012 PUMA population in that county. Finally, we convert the average subsidy by 2012 PUMAs to the average subsidy by consistent PUMAs as the average subsidy of all 2012 PUMAs that intersect with it, weighted by the fraction of the consistent PUMA's population that falls into that intersection. We are left with monthly subsidy levels by consistent PUMAs in 2014, which are summarized in Figure 6. As shown in the figure, these monthly subsidy levels for a 60year old with annual income of approximately $\$ 16$ thousand vary substantially, from a low of $\$ 209$ per month to a high of $\$ 976$ per month. On average, the monthly subsidy level is $\$ 502$ per month.

The correlation with baseline uninsurance shown in Figure 4 is 0.163 , suggesting that any variation in outcomes from differences across subsidies can be separately identified from that stemming from differences across baseline uninsurance rates. Figure 7 shows the fraction insured in PUMAs with subsidy levels that fall in the top and bottom quartile of the distribution. As shown in the figure, there is a level difference in the rates of insurance of insurance coverage and both 
sets of areas see increases in insurance coverage after the ACA is enacted. However, the spread between these two areas shrinks after the ACA's enactment, suggesting that places with higher subsidy levels saw larger increases in insurance coverage.

We examine this in a regression framework, augmenting our original specification with an additional interaction term using the demeaned level of monthly subsidy in each PUMA, divided by $\$ 100$. Specifically, we estimate the following regression equation:

(3) $I N S_{\text {iapt }}=\delta_{1}$ POST $_{t} \times$ Unins $_{p} \times$ Age60_64 $_{a}+\delta_{2}$ POST $_{t} \times$ Unins $_{p} \times$

$$
\begin{aligned}
& \text { Age60_64 } \times(\overline{\text { Subsidy }} / 100)_{p}+\beta X_{\text {iapt }}+\gamma_{t}+\mu_{a}+\theta_{p}+\alpha_{a t}+\varphi_{p t}+\omega_{a p}+ \\
& \theta_{p, \text { sub }}+\alpha_{a t, \text { sub }}+\varphi_{p t, \text { sub }}+\omega_{a p, \text { sub }}+\varepsilon_{\text {iapt }}
\end{aligned}
$$

where $(\overline{\text { Subsidy }} / 100)_{p}$ denotes the demeaned monthly subsidy in $\$ 100$ in PUMA $p$. The interpretation of $\delta_{1}$ is the DDD estimate for the average subsidy level, where $\delta_{2}$ indicates whether the outcome variable changed differentially in areas with high subsidies.

We report the results of estimating equation (3) with insurance outcomes in Table 10, and an analogous equation with labor market outcomes in Table 11. Table 10 shows evidence that places with higher subsidy levels had larger increases in insurance coverage after the ACA. Specifically, a $\$ 100$ change in the effective monthly subsidy increased insurance coverage by 5.2 percentage points for 60-64 year olds relative to 65-69 year olds for a given level of baseline uninsurance following the ACA. When we split insurance coverage by source, the coefficient estimates suggest that this increase came from directly purchased insurance and was somewhat offset by employer coverage; however, the DDDD estimates in Columns (2) - (6) are statistically insignificant. 
In Table 11, we examine whether labor market outcomes changed differentially in areas with higher effective subsidy levels. We find no evidence that labor force participation changed differentially in areas with higher subsidies, and only employment shows a marginally significant $(p<0.10)$ coefficient for the DDDD term across all of the extensive and intensive margin outcomes. We conclude that while higher subsidy levels induced higher levels of insurance coverage, this additional coverage does not appear to be associated with changes in labor market outcomes.

Note that our results may be attenuated due to the noise in our proxy for subsidy. First, converting from counties to consistent PUMAs required two separate steps and weighting by population estimates, so the subsidy values are likely measured with some error. Second, we use the 2014 subsidy level; however, effective subsidy levels changed each year as premiums changed. Therefore, it is possible that finer geographic identifiers and more refined premium data would provide additional precision in the estimates.

\section{Robustness Checks}

We explore the sensitivity of our results to several changes in our empirical specification. First, we examine whether our results continue to hold when we limit our sample to ages 62-67, allowing for a comparison of age groups that are plausibly more similar than our broader sample of individuals aged 60 to 69. As shown in Appendix Tables A.2 - A.5, these results are qualitatively and quantitatively similar to our main findings.

We also perform a falsification test in which we include only those between the ages of 5564, and look for changes in 55-59 year olds relative to 60-64 year olds, since both groups were affected by the ACA. Here, we find results that are small and statistically insignificant, bolstering 
the evidence that the results we find when comparing 60-64 year olds to 65-69 year olds represent meaningful changes for these groups resulting from the ACA (Appendix Tables A.6 - A.9).

\section{CONCLUSION}

The Affordable Care Act substantially increased health insurance coverage among the nonelderly in the U.S. Previous work has investigated the effect of the ACA on labor market outcomes. Taken together, the results from this previous research suggest that this landmark legislation had little effect on the labor market. However, most studies have considered a much broader age segment than the 60-64 age group that we consider in our study.

For three reasons, the near elderly are the group whose labor market outcomes are most likely to be affected by the ACA-induced increases in health insurance coverage. First, health insurance is more valuable to the near elderly given their higher expected health care costs. Second, the premium subsidies provided to the near elderly were on average much higher than those received by their younger counterparts. Third and perhaps most importantly, the elasticity of labor supply among the near elderly is higher than among younger adults.

Our results indicate that the ACA reduced the near elderly (60-64) labor force by about 1.1 percent (110 thousand) from 2014 through 2018. While the ACA may have affected labor market outcomes for younger adults as well, for the reasons cited above this is the age group most likely to be affected. In light of this, the reduction that we estimate is substantially smaller than would be implied by the often-cited CBO estimates of 2.0 to 2.5 million (CBO, 2014). These labor market effects should be considered in any overall assessment of the ACA along with its effects on health outcomes and on economic well-being. 


\section{REFERENCES}

Aizer, Anna, and Jeffrey Grogger, 2003. "Parental Medicaid Expansions and Health Insurance Coverage.” NBER Working Paper No. 9907, National Bureau of Economic Research, Cambridge, MA.

Aslim, Erkmen Giray, 2019. "The Relationship Between Health Insurance and Early Retirement: Evidence from the Affordable Care Act.” Eastern Economic Journal. 45: 112-140.

Autor, David H., and Mark G. Duggan, 2003. "The Rise in Disability Rolls and the Decline in Unemployment." The Quarterly Journal of Economics, 118(1): 157-206.

Ayyagari, Padmaja, 2019. "Health Insurance and Early Retirement: Evidence from the Affordable Care Act.” American Journal of Health Economics, 5(4): 533-560.

Buchmueller, Thomas, Helen C. Levy, and Robert G. Valletta, 2018. "The Affordable Care Act's Medicaid Expansion and Unemployment." Working paper.

Congressional Budget Office, 2014. "Labor Market Effects of the Affordable Care Act: Updated Estimates.” Congressional Budget Office, Washington, DC.

Courtemanche, Charles, James Marton, Benjamin Ukert, Aaron Yelowitz, and Daniela Zapata, 2017. "Impacts of the Affordable Care Act on Health Insurance Coverage in Medicaid Expansion and Non-Expansion States." Journal of Policy Analysis and Management, 36(1): 178-210.

Currie, Janet and Jonathan Gruber, 1996. "Saving Babies: The Efficacy and Cost of Recent Changes in the Medicaid Eligibility of Pregnant Women," Journal of Political Economy, 104(6): 1263-1296.

Currie, Janet and Jonathan Gruber, 1996b. "Health Insurance Eligibility, Utilization of Medical Care, and Child Health," Quarterly Journal of Economics, 111(2): 431-466.

Cutler, David M., and Jonathan Gruber, 1996. "Does Public Insurance Crowd Out Private Insurance?" The Quarterly Journal of Economics, 111(2): 391-430.

Duggan, Mark, Gopi Shah Goda, and Emilie Jackson, 2019. "The Effects of the Affordable Care Act on Health Insurance Coverage and Labor Market Outcomes," National Tax Journal, 72(2): 261-322

Finkelstein, Amy, 2007. "The Aggregate Effects of Health Insurance: Evidence from the Introduction of Medicare," Quarterly Journal of Economics, 122(1): 1-37.

Finkelstein, Amy and Robin McKnight, 2008. "What Did Medicare Do? The Initial Impact of Medicare on Mortality and Out of Pocket Medical Spending," Journal of Public Economics, 92(7): 1644-1669. 
Frean, Molly, Jonathan Gruber, and Benjamin D. Sommers, 2017. "Premium Subsidies, the Mandate, and Medicaid Expansion: Coverage Effects of the Affordable Care Act," Journal of Health Economics, 53: 72-86.

Freed, Salama, 2017. "Insurance Take-Up Among the Near-Elderly in the Age of the Affordable Care Act," Manuscript. https://www.semanticscholar.org/paper/Insurance-Take-UpAmong-the-Near-Elderly-in-the-AgeFreed/ce2b16efa0fe5072a8c661046d15d5597833f995.

French, Eric, 2005. "The Effects of Health, Wealth, and Wages on Labour Supply and Retirement Behaviour," Review of Economic Studies, 72 (2), 395-427.

Gooptu, Angshuman, Asako S. Moriya, Kosali I. Simon, and Benjamin D. Sommers. 2016. "Medicaid Expansion Did Not Result in Significant Employment Changes Or Job Reductions In 2014.” Health Affairs, 35(1): 111-118.

Gruber, Jonathan and Brigitte C. Madrian, 2002. "Health Insurance, Labor Supply, and Job Mobility: A Critical Review of the Literature." In McLaughlin, Catherine (ed.) Health Policy and the Uninsured. Washington, D.C.: Urban Institute Press, 2004.

Gustman, Alan L., Thomas L. Steinmeier, and Nahid Tabatabai, 2019. "The Affordable Care Act as Retiree Health Insurance: Implications for Retirement and Social Security Claiming." Journal of Pension Economics \& Finance, 18(3): 415-449.

Hamersma, Sarah and Matthew Kim, 2013. "Participation and Crowd-Out: Assessing the Effects of Parental Medicaid Expansions.” Journal of Health Economics, 32(1): 160-171.

Kaestner, Robert, Bowen Garrett, Anuj Gangopadhyaya, and Caitlyn Fleming, 2017. "Effects of ACA Medicaid Expansions on Health Insurance Coverage and Labor Supply." Journal of Policy Analysis and Management, 36: 608-642.

Kolstad, Jonathan T., and Amanda E. Kowalski, 2012. "The impact of health care reform on hospital and preventive care: Evidence from Massachusetts." Journal of Public Economics, 96(11-12): 909-929.

Levy, H., Thomas C Buchmueller, and Sayeh Nikpay, 2018. "Health Reform and Retirement." Journal of Gerontology and Social Sciences Series B: Psychological and Social Sciences, 73(4): 713-722.

Long, Sharon K, Lea Bart, Michael Karpman, Adele Shartzer, and Stephen Zuckerman, 2017. "Sustained gains in coverage, access, and affordability under the ACA: A 2017 update. Health Affairs, 36(9)," 1656-1662.

Madrian, Brigitte C., 1994. "Employment-Based Health Insurance and Job Mobility: Is There Evidence of Job Lock?," Quarterly Journal of Economics 109(1): 27-54. 
Miller, Sarah, 2012. "The Effect of Insurance on Emergency Room Visits: An Analysis of the 2006 Massachusetts Health Reform," Journal of Public Economics, 96(11):893-908.

Ruggles, Steven, Sarah Flood, Ronald Goeken, Josiah Grover, Erin Meyer, Jose Pacas and Matthew Sobek. IPUMS USA: Version 10.0 [American Community Survey 2010-2018]. Minneapolis, MN: IPUMS, 2020. https://doi.org/10.18128/D010.V10.0

Sommers, Benjamin D., Thomas Musco, Kenneth Finegold, Munira Z. Gunja, Amy Burke, and Audrey M. McDowell, 2014. "Health Reform and Changes in Health Insurance Coverage in 2014." New England Journal of Medicine, 371(9): 867-874.

Sommers, Benjamin D., Munira Z. Gunja, Kenneth Finegold, and Thomas Musco, 2015. "Changes in Self-reported Insurance Coverage, Access to Care, and Health Under the Affordable Care Act.” Journal of the American Medical Association, 314(4): 366-374.

Sommers, Benjamin D., Kao-Ping Chua, Genevieve M. Kenney, Sharon K. Long, and Stacey McMorrow, 2016. "California's Early Coverage Expansion under the Affordable Care Act: A County-Level Analysis.” Health Services Research, 51(3): 825-845.

Wood, Kevin, 2019. "Health Insurance Reform and Retirement: Evidence from the Affordable Care Act." Health Economics, 28(12): 1462-1475 
Figure 1

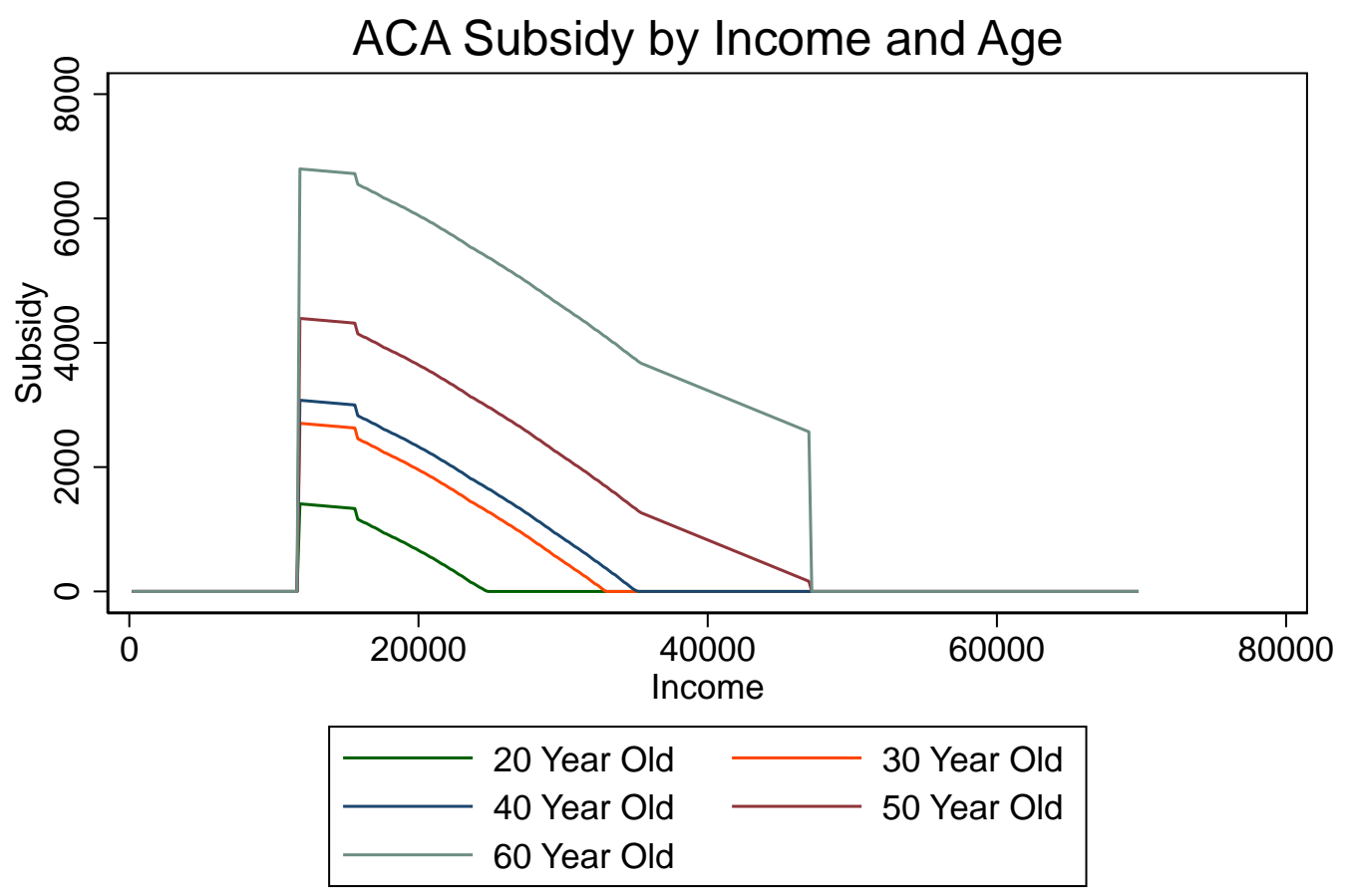

Note: Subsidy calculated for single person in 2015 for all scenarios. 
Figure 2

Family Healthcare Spending Exceed $\$ 2000$ Annually

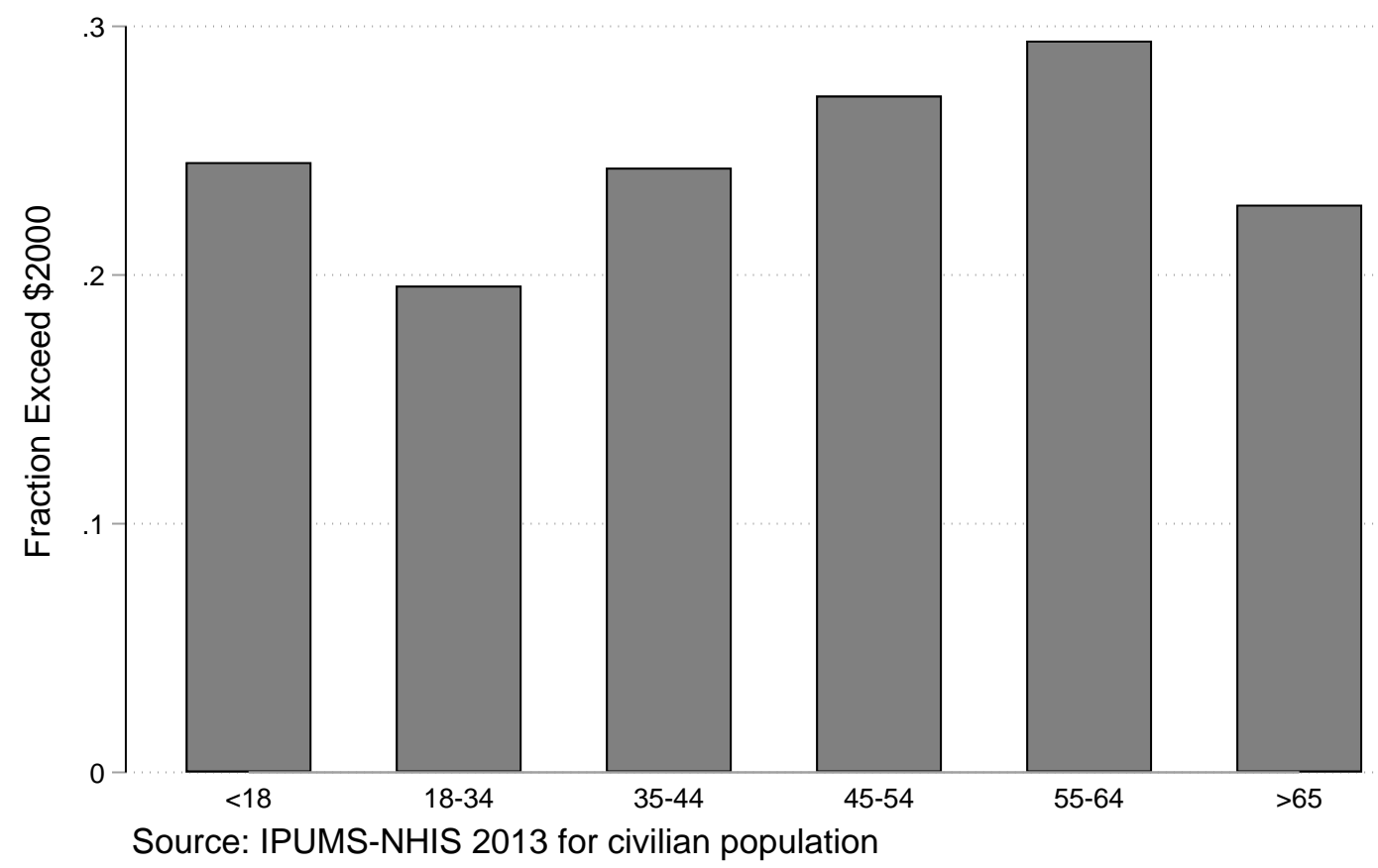


Figure 3

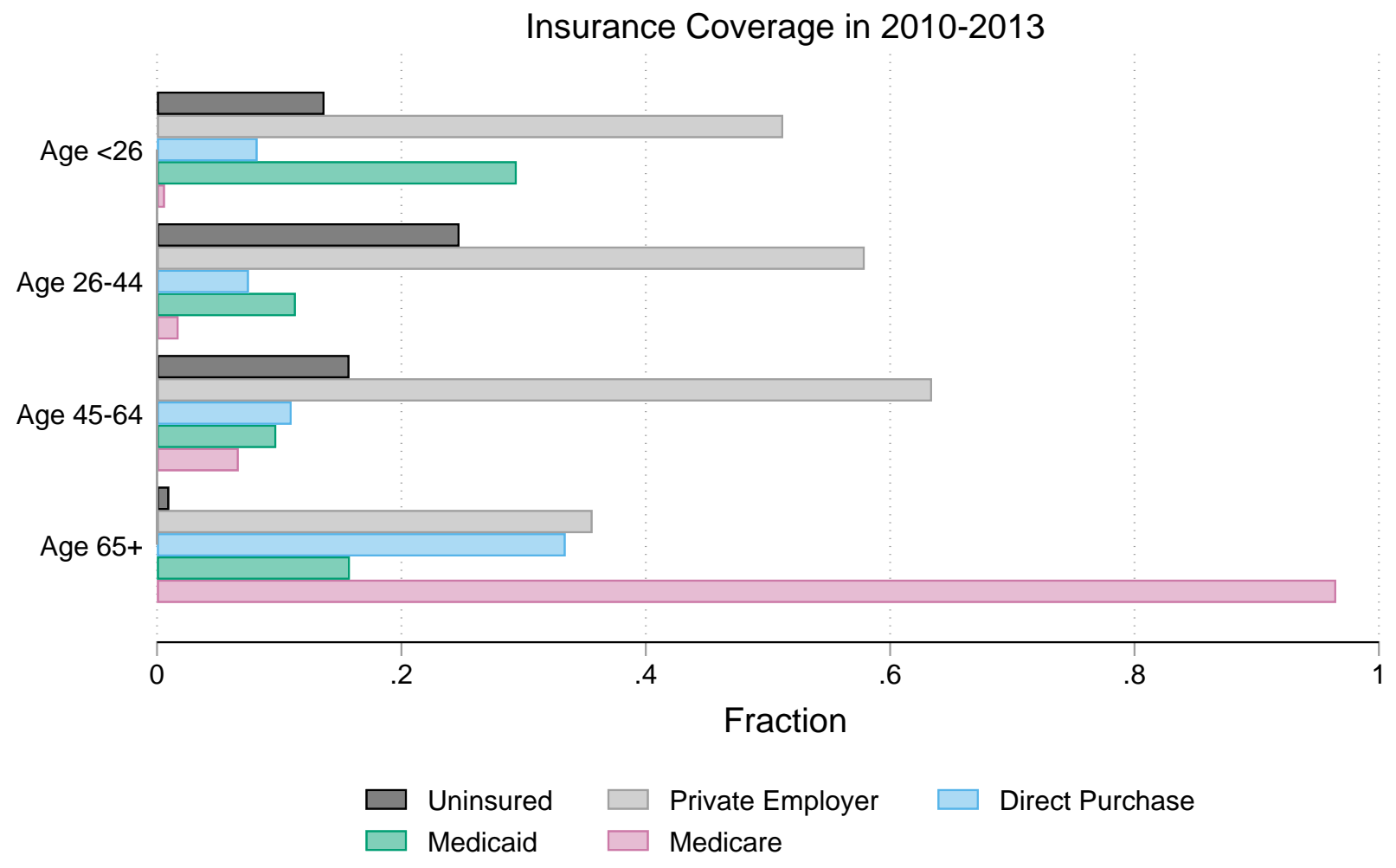

Source: IPUMS ACS 2010-2013, civilians 
Figure 4

Fraction Age 60-64 Uninsured in 2010-2013

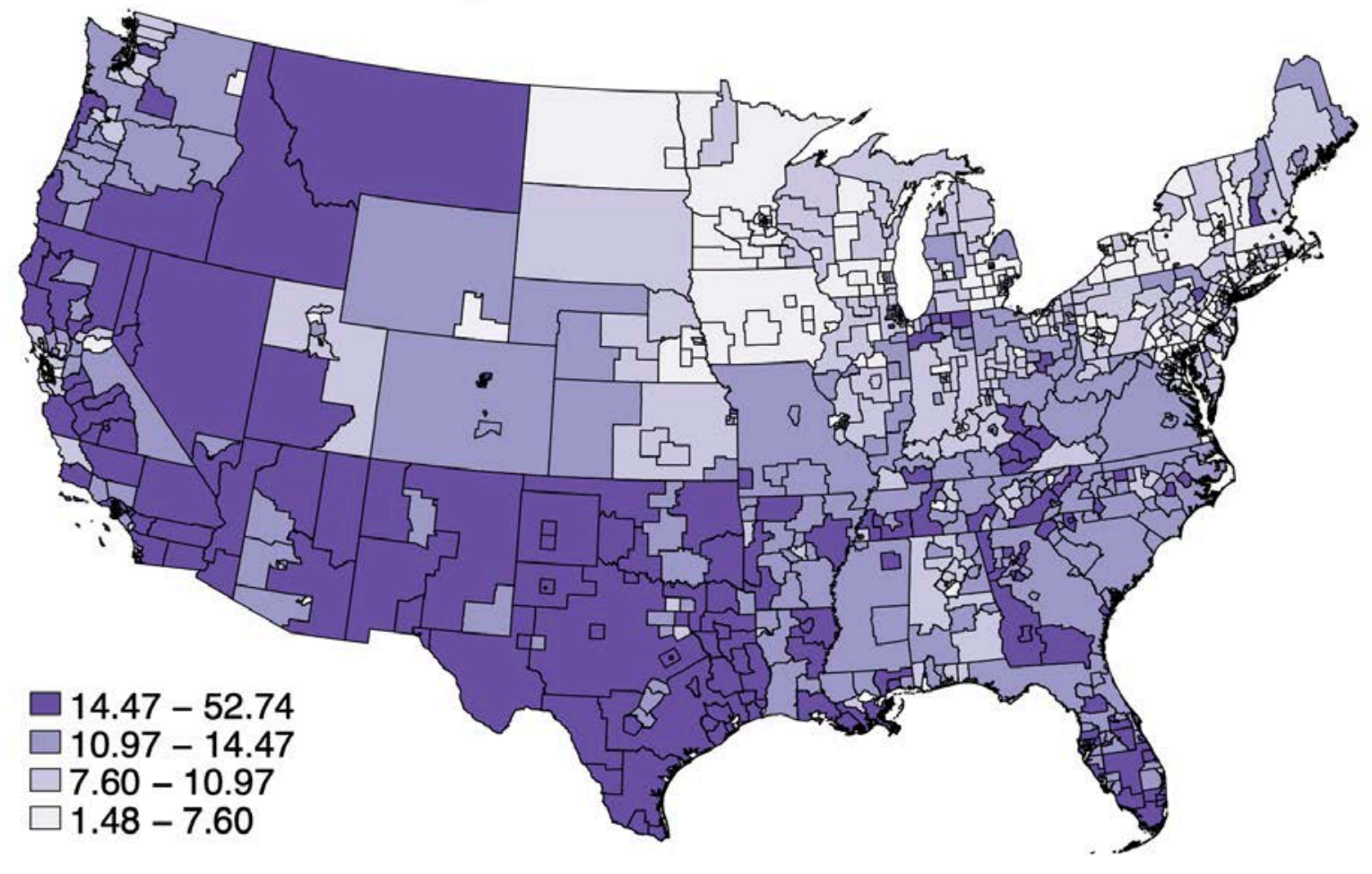




\section{Figure 5}

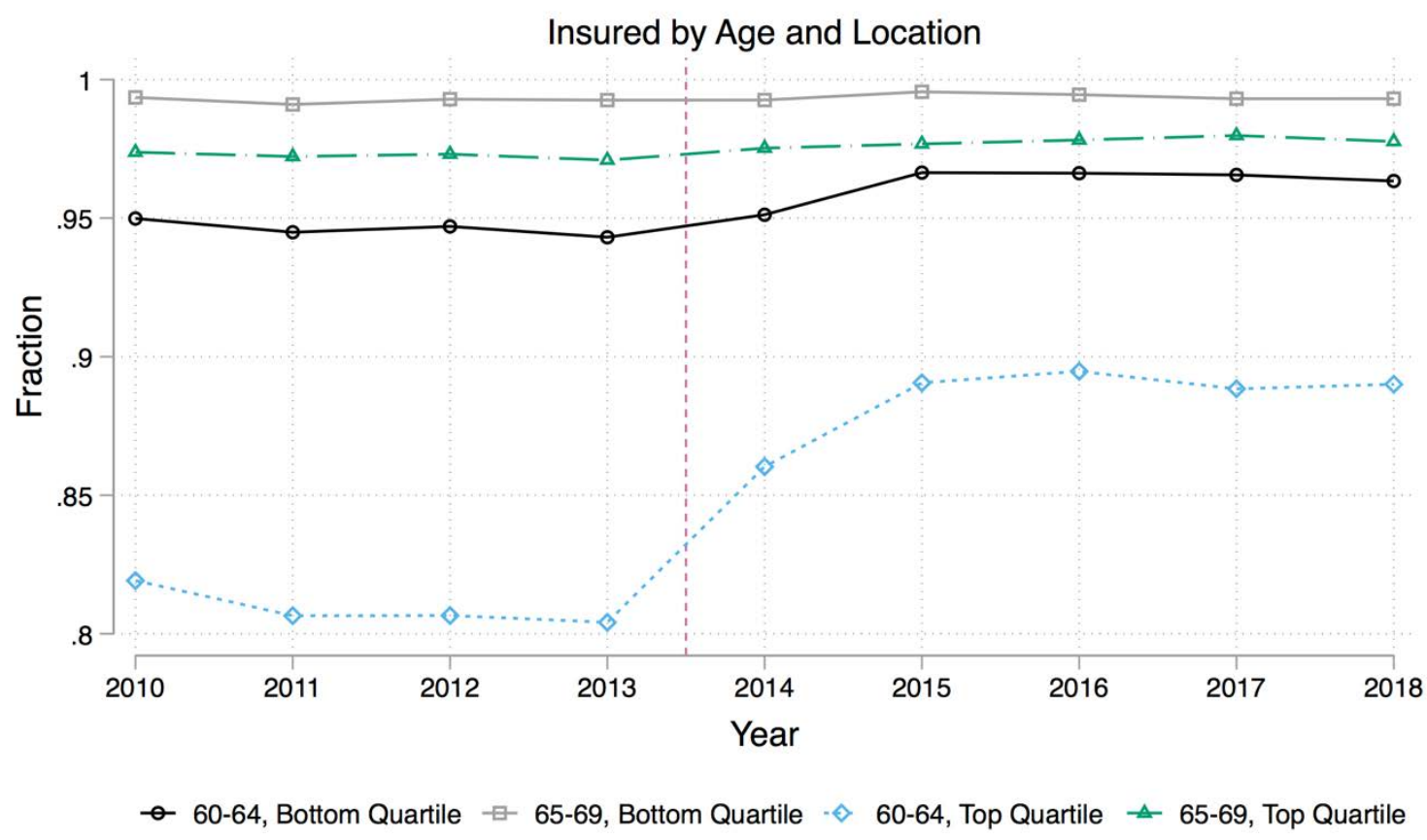

Source: ACS 2010-2018, civilians. Insured status and number coverage excludes IHS. Vertical line separates pre and post-ACA periods. 
Figure 6

Monthly Subsidy by Consistent PUMA, 2014

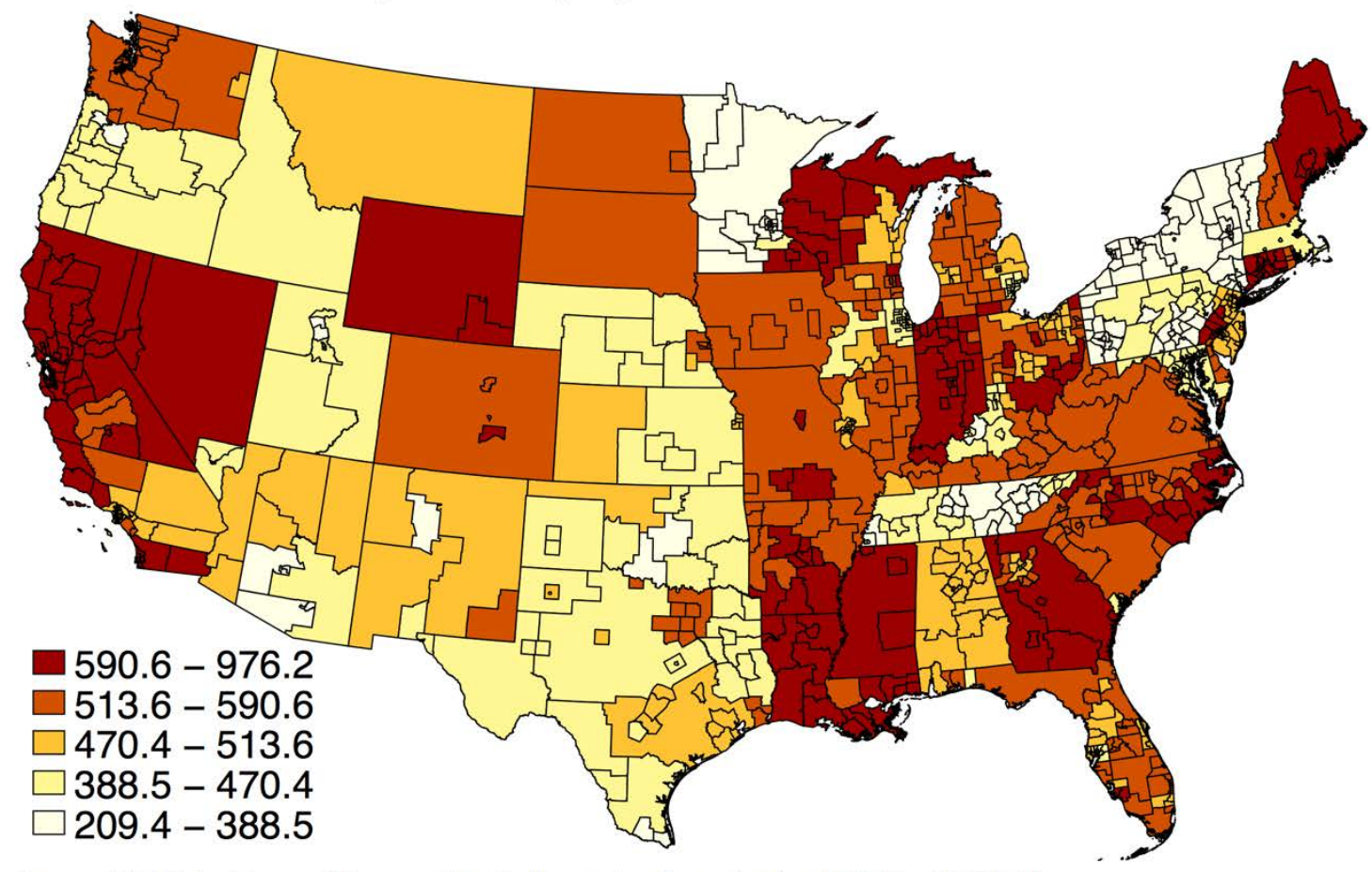

Source: KFF Data, For age 60 year old in single member household and MAGI $=133 \% \mathrm{FPL}$ 


\section{Figure 7}

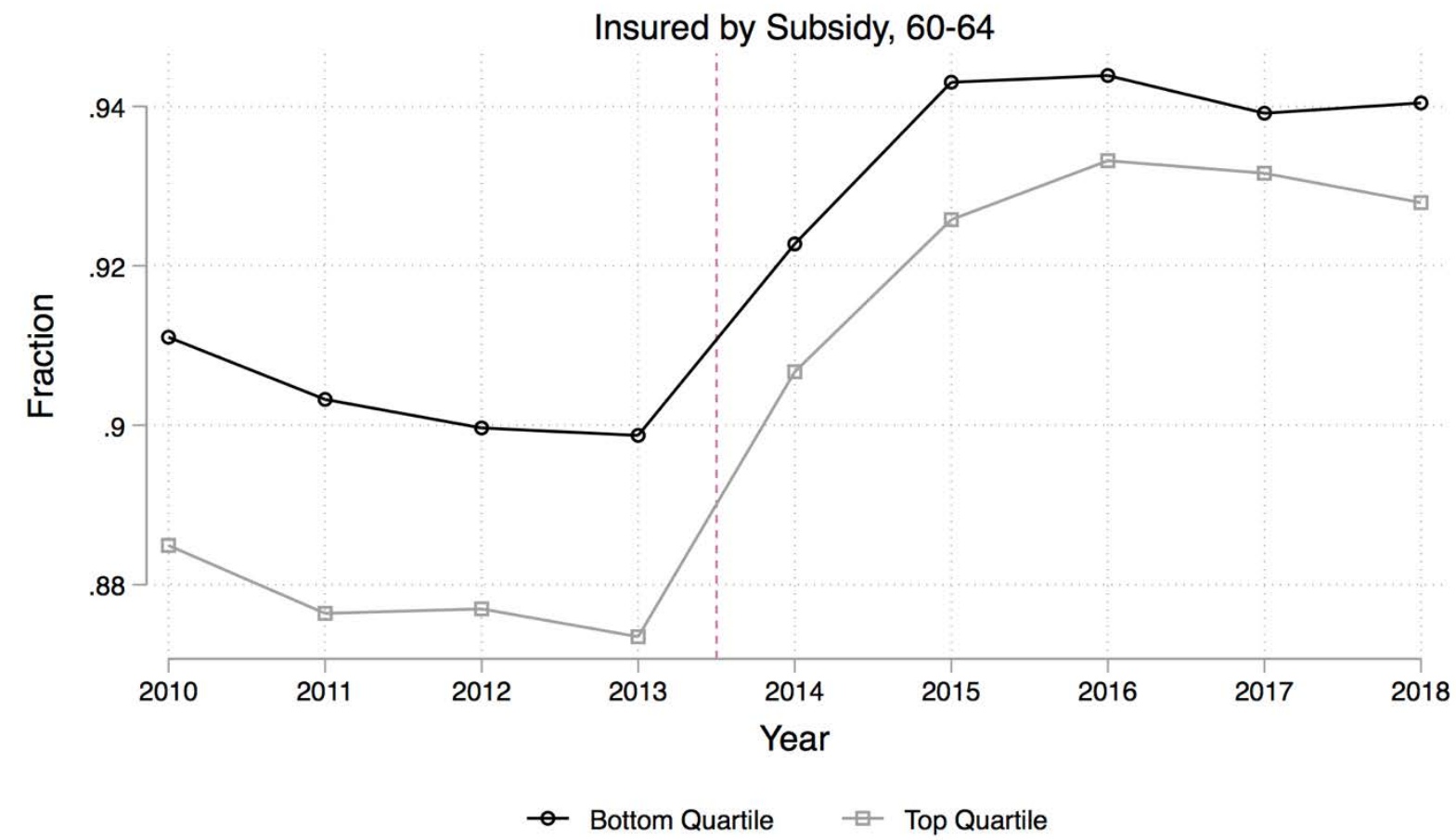

Source: ACS 2010-2018, civilians and KFF Subsidy Data. Insured status excludes IHS. Vertical line separates pre and post-ACA periods. 


\section{Table 1}

Demographics and Labor Market Outcomes by Year, Age 60-69

\begin{tabular}{|c|c|c|c|c|c|c|c|c|c|}
\hline & 2010 & 2011 & 2012 & 2013 & 2014 & 2015 & 2016 & 2017 & 2018 \\
\hline Female & 0.525 & 0.524 & 0.525 & 0.525 & 0.524 & 0.525 & 0.526 & 0.524 & 0.525 \\
\hline White & 0.828 & 0.827 & 0.823 & 0.819 & 0.815 & 0.811 & 0.807 & 0.800 & 0.796 \\
\hline Black & 0.099 & 0.100 & 0.102 & 0.104 & 0.105 & 0.105 & 0.108 & 0.111 & 0.114 \\
\hline Asian & 0.042 & 0.041 & 0.042 & 0.045 & 0.046 & 0.047 & 0.048 & 0.049 & 0.050 \\
\hline Other Race & 0.032 & 0.032 & 0.033 & 0.033 & 0.034 & 0.036 & 0.037 & 0.039 & 0.040 \\
\hline Hispanic & 0.080 & 0.081 & 0.084 & 0.085 & 0.088 & 0.091 & 0.093 & 0.095 & 0.099 \\
\hline Not i & 0.552 & 0.554 & 0.554 & 0.553 & 0.556 & 0.557 & 0.554 & 0.545 & 0.539 \\
\hline Em & 0.410 & 0.412 & 0.417 & 0.422 & 0.424 & 0.426 & 0.430 & 0.440 & 0.447 \\
\hline Une & 0.037 & 0.034 & 0.029 & 0.025 & 0.020 & 0.017 & 0.016 & 0.015 & 0.014 \\
\hline Self $\mathrm{E}$ & 0.069 & 0.069 & 0.070 & 0.068 & 0.071 & 0.070 & 0.072 & 0.072 & 0.072 \\
\hline Part-Time & 0.083 & 0.082 & 0.083 & 0.082 & 0.081 & 0.082 & 0.082 & 0.082 & 0.081 \\
\hline Hours & 37.379 & 37.599 & 37.612 & 37.764 & 37.885 & 37.991 & 37.934 & 38.091 & 38.163 \\
\hline Insured & 0.927 & 0.923 & 0.924 & 0.924 & 0.942 & 0.954 & 0.957 & 0.954 & 0.953 \\
\hline Num. Cov. & 1.419 & 1.398 & 1.409 & 1.392 & 1.404 & 1.419 & 1.424 & 1.403 & 1.396 \\
\hline Employe & 0.533 & 0.526 & 0.521 & 0.506 & 0.497 & 0.489 & 0.484 & 0.482 & 0.482 \\
\hline Direc & 0.212 & 0.197 & 0.197 & 0.192 & 0.201 & 0.212 & 0.215 & 0.206 & 0.206 \\
\hline Tricare/Military & 0.044 & & & & & 0.041 & 0.041 & 0.040 & 0.038 \\
\hline & 108 & & & 0.112 & & 0.132 & 0.137 & 0.139 & 0.143 \\
\hline Medicare & 0.460 & 0.457 & & 0.477 & 0.482 & 0.486 & 0.490 & 0.483 & 0.480 \\
\hline Observations & 344961 & 365384 & 377680 & 385525 & 399877 & 414044 & 427496 & 431862 & 443244 \\
\hline
\end{tabular}

Source: IPUMS ACS 2010-2018, age 60-69 civilians. 


\section{Table 2}

Insurance Outcomes by Age Group and Uninsured Status, 60-69

\begin{tabular}{lcccccc}
\hline & $(1)$ & $(2)$ & $(3)$ & $(4)$ & $(5)$ & $(6)$ \\
& Insured & Num. Cov. & Employer/Union & Direct Purchase & Medicaid & Medicare \\
\hline Unins x 60-64 x Post & $0.401^{* * *}$ & $0.275^{* * *}$ & $0.0577^{* *}$ & $0.128^{* * *}$ & $0.102^{* * *}$ & $-0.0303^{*}$ \\
& $(0.0222)$ & $(0.0395)$ & $(0.0259)$ & $(0.0264)$ & $(0.0341)$ & $(0.0178)$ \\
\hline Obs. & 3590073 & 3590073 & 3590073 & 3590073 & 3590073 & 3590073 \\
Mean Dep. Var & 0.879 & 1.060 & 0.609 & 0.143 & 0.0991 & 0.117 \\
SD Dep. Var & 0.327 & 0.613 & 0.488 & 0.350 & 0.299 & 0.321 \\
\hline
\end{tabular}

Notes: Robust standard errors clustered by consistent puma in the parentheses. Observations are 60-69 year old civilians

in 2010-2018 from IPUMS-ACS. Includes cons. puma, year, age, age by year, cons. puma by year, and age by cons. puma FE.

Regressions control for sex, race, ethnicity, and education. Uninsured is demeaned share of 60-64 of cons. puma in 2010-2013 uninsured.

${ }^{*} p<0.10,{ }^{* *} p<0.05,{ }^{* * *} p<0.01$

\section{Table 3}

Insurance Outcomes by Age Group, Uninsured, and Expan Status 60-69

\begin{tabular}{|c|c|c|c|c|c|c|}
\hline & $\begin{array}{c}(1) \\
\text { Insured }\end{array}$ & $\begin{array}{c}(2) \\
\text { Num. Cov. }\end{array}$ & $\begin{array}{c}(3) \\
\text { Employer/Union }\end{array}$ & $\begin{array}{c}(4) \\
\text { Direct Purchase }\end{array}$ & $\begin{array}{c}(5) \\
\text { Medicaid }\end{array}$ & $\begin{array}{c}(6) \\
\text { Medicare }\end{array}$ \\
\hline Unins $\mathrm{x} 60-64 \mathrm{x}$ Post & $\begin{array}{l}0.309^{* * *} \\
(0.0390)\end{array}$ & $\begin{array}{l}0.226^{* * *} \\
(0.0616)\end{array}$ & $\begin{array}{c}0.0609 \\
(0.0378)\end{array}$ & $\begin{array}{l}0.159^{* * *} \\
(0.0344)\end{array}$ & $\begin{array}{l}-0.0297 \\
(0.0259)\end{array}$ & $\begin{array}{l}-0.0131 \\
(0.0257)\end{array}$ \\
\hline Unins $x$ 60-64 x Post $x$ Expan & $\begin{array}{l}0.231^{* * *} \\
(0.0426)\end{array}$ & $\begin{array}{c}0.135^{*} \\
(0.0778)\end{array}$ & $\begin{array}{l}-0.0140 \\
(0.0522)\end{array}$ & $\begin{array}{l}-0.106^{* *} \\
(0.0451)\end{array}$ & $\begin{array}{l}0.331^{* * *} \\
(0.0415)\end{array}$ & $\begin{array}{l}-0.0376 \\
(0.0353)\end{array}$ \\
\hline Obs. & 3590073 & 3590073 & 3590073 & 3590073 & 3590073 & 3590073 \\
\hline Mean Dep. Var (Ex) & 0.887 & 1.053 & 0.622 & 0.142 & 0.107 & 0.106 \\
\hline SD Dep. Var (Ex) & 0.316 & 0.584 & 0.485 & 0.349 & 0.309 & 0.308 \\
\hline Mean Dep. Var (Non-Ex) & 0.870 & 1.067 & 0.596 & 0.144 & 0.0914 & 0.127 \\
\hline SD Dep. Var (Non-Ex) & 0.336 & 0.640 & 0.491 & 0.351 & 0.288 & 0.333 \\
\hline
\end{tabular}

Note: Robust standard errors in parentheses clustered by consistent puma. Observations are 60-69 year old civilians in 2010-2018. Expan refers to states that expanded Medicaid in 2014. Includes cons. puma, year, age, age by year, cons. puma by year, age by cons. puma FE, and age by year by expansion status FE. Regressions control for sex, race, ethnicity, and education. Uninsured is demeaned share of 60-64 of of cons. puma in 2010-2013 uninsured.

${ }^{*} p<0.10,{ }^{* *} p<0.05,{ }^{* * *} p<0.01$ 


\section{Table 4}

Insurance Coverage by Age Group and Uninsured Status (Het.), 60-69

\begin{tabular}{lcccccccc}
\hline & $(1)$ & $(2)$ & $(3)$ & $(4)$ & $(5)$ & $(6)$ & $(7)$ & $(8)$ \\
& Non-Minority & Minority & HSG or Less & College & Male & Female & Non-married & Married \\
\hline Unins x 60-64 x Post & $0.241^{* * *}$ & $0.474^{* * *}$ & $0.485^{* * *}$ & $0.277^{* * *}$ & $0.357^{* * *}$ & $0.435^{* * *}$ & $0.366^{* * *}$ & $0.396^{* * *}$ \\
& $(0.0198)$ & $(0.0398)$ & $(0.0309)$ & $(0.0202)$ & $(0.0260)$ & $(0.0253)$ & $(0.0309)$ & $(0.0255)$ \\
\hline Obs. & 2793749 & 796170 & 1717643 & 1872430 & 1705194 & 1884879 & 1137206 & 2452867 \\
Mean Dep. Var & 0.907 & 0.793 & 0.833 & 0.919 & 0.886 & 0.872 & 0.824 & 0.905 \\
SD Dep. Var & 0.291 & 0.405 & 0.373 & 0.274 & 0.318 & 0.334 & 0.380 & 0.293 \\
\hline
\end{tabular}

Notes: Robust standard errors clustered by consistent puma in the parentheses. Observations are 60-69 year old civilians in 2010-2018 from IPUMS-ACS. Includes cons. puma, year, age, age by year, cons. puma by year, and age by cons. puma FE.

Regressions control for sex, race, ethnicity, and education. Uninsured is demeaned share of 60-64 of cons. puma in 2010-2013 uninsured.

Non-minority refers to white, non-hispanic. Married includes separated.

${ }^{*} p<0.10,{ }^{* *} p<0.05,{ }^{* * *} p<0.01$

\section{Table 5}

Insurance Coverage by Age Group, Uninsured and Expan Status (Het.), 60-69

\begin{tabular}{lcccccccc}
\hline & $(1)$ & $(2)$ & $(3)$ & $(4)$ & $(5)$ & $(6)$ & $(7)$ & $(8)$ \\
& Non-Minority & Minority & HSG or Less & College & Male & Female & Non-married & $\begin{array}{c}(8) \\
\text { Married }\end{array}$ \\
\hline Unins x 60-64 x Post & $0.170^{* * *}$ & $0.369^{* * *}$ & $0.382^{* * *}$ & $0.208^{* * *}$ & $0.272^{* * *}$ & $0.337^{* * *}$ & $0.259^{* * *}$ & $0.316^{* * *}$ \\
& $(0.0236)$ & $(0.0688)$ & $(0.0453)$ & $(0.0373)$ & $(0.0472)$ & $(0.0388)$ & $(0.0512)$ & $(0.0425)$ \\
Unins x 60-64 x Post x Expan & $0.197^{* * *}$ & $0.250^{* * *}$ & $0.263^{* * *}$ & $0.176^{* * *}$ & $0.216^{* * *}$ & $0.244^{* * *}$ & $0.262^{* * *}$ & $0.203^{* * *}$ \\
& $(0.0335)$ & $(0.0782)$ & $(0.0556)$ & $(0.0428)$ & $(0.0537)$ & $(0.0457)$ & $(0.0631)$ & $(0.0491)$ \\
\hline Obs. & 2793749 & 796170 & 1717643 & 1872430 & 1705194 & 1884879 & 1137206 & 2452867 \\
Mean Dep. Var (Ex) & 0.916 & 0.807 & 0.842 & 0.923 & 0.893 & 0.882 & 0.841 & 0.910 \\
SD Dep. Var (Ex) & 0.277 & 0.395 & 0.365 & 0.266 & 0.310 & 0.323 & 0.366 & 0.286 \\
Mean Dep. Var (Non-Ex) & 0.898 & 0.778 & 0.825 & 0.913 & 0.878 & 0.862 & 0.808 & 0.899 \\
SD Dep. Var (Non-Ex) & 0.303 & 0.416 & 0.380 & 0.281 & 0.327 & 0.345 & 0.394 & 0.301 \\
\hline
\end{tabular}

Note: Robust standard errors in parentheses clustered by consistent puma. Observations are 60-69 year old civilians in 2010-2018. Expan refers to states that expanded Medicaid in 2014. Includes cons. puma, year, age, age by year, cons. puma by year, age by cons. puma FE, and age by year by expansion status FE. Regressions control for sex, race, ethnicity, and education. Uninsured is demeaned share of 60-64 of

of cons. puma in 2010-2013 uninsured. Non-minority refers to white, non-Hispanic. Married includes separated.

* $p<0.10,{ }^{*} p<0.05,{ }^{* *} p<0.01$ 


\section{Table 6}

Labor Outcomes by Age Group and Uninsured Status, 60-69

\begin{tabular}{lcccccc}
\hline & $(1)$ & $(2)$ & $(3)$ & $(4)$ & $(5)$ & $(6)$ \\
& Not in Labor Force & Employed & Unemployed & Self Employed & Part-Time & Hours \\
\hline Unins x 60-64 x Post & $0.0536^{* *}$ & -0.0287 & $-0.0249^{* * *}$ & $-0.0284^{* *}$ & -0.00564 & 0.227 \\
& $(0.0220)$ & $(0.0217)$ & $(0.00763)$ & $(0.0120)$ & $(0.0117)$ & $(1.082)$ \\
\hline Obs. & 3590073 & 3590073 & 3590073 & 3590073 & 3590073 & 1514828 \\
Mean Dep. Var & 0.451 & 0.511 & 0.0386 & 0.0774 & 0.0797 & 38.91 \\
SD Dep. Var & 0.498 & 0.500 & 0.193 & 0.267 & 0.271 & 12.47 \\
\hline
\end{tabular}

Notes: Robust standard errors clustered by consistent puma in the parentheses. Observations are 60-69 year old civilians

in 2010-2018 from IPUMS-ACS. Includes cons. puma, year, age, age by year, cons. puma by year, and age by cons. puma FE.

Regressions control for sex, race, ethnicity, and education. Uninsured is demeaned share of 60-64 of cons. puma in 2010-2013 uninsured.

${ }^{*} p<0.10,{ }^{* *} p<0.05,{ }^{* * *} p<0.01$

\section{Table 7}

Labor Outcomes by Age Group, Uninsured, and Expan Status 60-69

\begin{tabular}{|c|c|c|c|c|c|c|}
\hline & $\begin{array}{c}(1) \\
\text { Not in Labor Force }\end{array}$ & $\begin{array}{c}(2) \\
\text { Employed }\end{array}$ & $\begin{array}{c}(3) \\
\text { Unemployed }\end{array}$ & $\begin{array}{c}(4) \\
\text { Self Employed }\end{array}$ & $\begin{array}{c}(5) \\
\text { Part-Time }\end{array}$ & $\begin{array}{c}(6) \\
\text { Hours }\end{array}$ \\
\hline Unins x 60-64 x Post & $\begin{array}{l}0.0744^{* *} \\
(0.0324)\end{array}$ & $\begin{array}{l}-0.0594^{*} \\
(0.0310)\end{array}$ & $\begin{array}{l}-0.0150 \\
(0.0105)\end{array}$ & $\begin{array}{c}-0.0426^{* *} \\
(0.0172)\end{array}$ & $\begin{array}{l}-0.0132 \\
(0.0165)\end{array}$ & $\begin{array}{c}1.831 \\
(1.531)\end{array}$ \\
\hline Unins x 60-64 x Post x Expan & $\begin{array}{l}-0.0248 \\
(0.0448)\end{array}$ & $\begin{array}{c}0.0443 \\
(0.0441)\end{array}$ & $\begin{array}{l}-0.0195 \\
(0.0153)\end{array}$ & $\begin{array}{c}0.0261 \\
(0.0241)\end{array}$ & $\begin{array}{c}0.0164 \\
(0.0235)\end{array}$ & $\begin{array}{l}-2.768 \\
(2.145)\end{array}$ \\
\hline Obs. & 3590073 & 3590073 & 3590073 & 3590073 & 3590073 & 1514828 \\
\hline Mean Dep. Var (Ex) & 0.435 & 0.523 & 0.0419 & 0.0815 & 0.0835 & 38.64 \\
\hline SD Dep. Var (Ex) & 0.496 & 0.499 & 0.200 & 0.274 & 0.277 & 12.43 \\
\hline Mean Dep. Var (Non-Ex) & 0.467 & 0.498 & 0.0353 & 0.0733 & 0.0758 & 39.20 \\
\hline SD Dep. Var (Non-Ex) & 0.499 & 0.500 & 0.184 & 0.261 & 0.265 & 12.51 \\
\hline
\end{tabular}




\section{Table 8}

Not in the Labor Force by Age Group and Uninsured Status (Het.), 60-69

\begin{tabular}{lcccccccc}
\hline & $(1)$ & $(2)$ & $(3)$ & $(4)$ & $(5)$ & $(6)$ & $(7)$ & $(8)$ \\
& Non-Minority & Minority & HSG or Less & College & Male & Female & Non-married & Married \\
\hline Unins x 60-64 x Post & 0.0448 & -0.00641 & $0.0907^{* * *}$ & 0.00296 & $0.0620^{*}$ & 0.0456 & 0.0247 & $0.0576^{* *}$ \\
& $(0.0314)$ & $(0.0357)$ & $(0.0301)$ & $(0.0323)$ & $(0.0372)$ & $(0.0291)$ & $(0.0384)$ & $(0.0286)$ \\
\hline Obs. & 2793749 & 796170 & 1717643 & 1872430 & 1705194 & 1884879 & 1137206 & 2452867 \\
Mean Dep. Var & 0.437 & 0.492 & 0.531 & 0.380 & 0.401 & 0.496 & 0.483 & 0.435 \\
SD Dep. Var & 0.496 & 0.500 & 0.499 & 0.485 & 0.490 & 0.500 & 0.500 & 0.496 \\
\hline
\end{tabular}

Notes: Robust standard errors clustered by consistent puma in the parentheses. Observations are 60-69 year old civilians

in 2010-2018 from IPUMS-ACS. Includes cons. puma, year, age, age by year, cons. puma by year, and age by cons. puma FE.

Regressions control for sex, race, ethnicity, and education. Uninsured is demeaned share of 60-64 of cons. puma in 2010-2013 uninsured.

Non-minority refers to white, non-hispanic. Married includes separated.

${ }^{*} p<0.10,{ }^{* *} p<0.05,{ }^{* * *} p<0.01$

\section{Table 9}

Not in the Labor Force by Age Group, Uninsured and Expan Status (Het.), 60-69

\begin{tabular}{lcccccccc}
\hline & $\begin{array}{c}(1) \\
\text { Non-Minority }\end{array}$ & $\begin{array}{c}(2) \\
\text { Minority }\end{array}$ & $\begin{array}{c}(3) \\
\text { HSG or Less }\end{array}$ & $\begin{array}{c}(4) \\
\text { College }\end{array}$ & $\begin{array}{c}(5) \\
\text { Male }\end{array}$ & $\begin{array}{c}(6) \\
\text { Female }\end{array}$ & $\begin{array}{c}(7) \\
\text { Non-married }\end{array}$ & $\begin{array}{c}(8) \\
\text { Married }\end{array}$ \\
\hline Unins x 60-64 x Post & 0.0630 & 0.0247 & 0.0673 & $0.0858^{*}$ & 0.0670 & $0.0851^{* *}$ & 0.0464 & $0.0747^{*}$ \\
& $(0.0497)$ & $(0.0528)$ & $(0.0443)$ & $(0.0501)$ & $(0.0590)$ & $(0.0379)$ & $(0.0605)$ & $(0.0425)$ \\
Unins x 60-64 x Post x Expan & -0.0121 & -0.0536 & 0.0504 & $-0.135^{*}$ & -0.00807 & -0.0491 & -0.0341 & -0.0110 \\
& $(0.0652)$ & $(0.0695)$ & $(0.0621)$ & $(0.0697)$ & $(0.0757)$ & $(0.0578)$ & $(0.0802)$ & $(0.0581)$ \\
\hline Obs. & 2793749 & 796170 & 1717643 & 1872430 & 1705194 & 1884879 & 1137206 & 2452867 \\
Mean Dep. Var (Ex) & 0.422 & 0.471 & 0.518 & 0.368 & 0.388 & 0.478 & 0.466 & 0.419 \\
SD Dep. Var (Ex) & 0.494 & 0.499 & 0.500 & 0.482 & 0.487 & 0.500 & 0.499 & 0.493 \\
Mean Dep. Var (Non-Ex) & 0.452 & 0.516 & 0.543 & 0.393 & 0.414 & 0.515 & 0.500 & 0.451 \\
SD Dep. Var (Non-Ex) & 0.498 & 0.500 & 0.498 & 0.489 & 0.493 & 0.500 & 0.500 & 0.498 \\
\hline
\end{tabular}

Note: Robust standard errors in parentheses clustered by consistent puma. Observations are 60-69 year old civilians in 2010-2018. Expan refers to states that expanded Medicaid in 2014. Includes cons. puma, year, age, age by year, cons. puma by year, age by cons. puma FE, and age by year by expansion status FE. Regressions control for sex, race, ethnicity, and education. Uninsured is demeaned share of 60-64 of of cons. puma in 2010-2013 uninsured. Non-minority refers to white, non-Hispanic. Married includes separated.

${ }^{*} p<0.10,{ }^{* *} p<0.05,{ }^{* * *} p<0.01$ 


\section{Table 10}

Insurance Outcomes by Age Group, Uninsured, and Subsidy 60-69

\begin{tabular}{lcccccc}
\hline & $(1)$ & $(2)$ & $(3)$ & $(4)$ & $(5)$ & $(6)$ \\
& Insured & Num. Cov. & Employer/Union & Direct Purchase & $\begin{array}{c}\text { Medicaid } \\
\text { Medicare }\end{array}$ \\
\hline Unins x 60-64 x Post & $0.409^{* * *}$ & $0.277^{* * *}$ & 0.0410 & $0.133^{* * *}$ & $0.112^{* * *}$ & $-0.0357^{*}$ \\
& $(0.0198)$ & $(0.0377)$ & $(0.0260)$ & $(0.0273)$ & $(0.0371)$ & $(0.0183)$ \\
Unins x 60-64 x Post x Subsidy $(/ 100)$ & $0.0515^{* *}$ & 0.0597 & -0.0171 & 0.0224 & 0.0230 & 0.0164 \\
& $(0.0226)$ & $(0.0462)$ & $(0.0296)$ & $(0.0232)$ & $(0.0290)$ & $(0.0159)$ \\
\hline Observations & 3567333 & 3567333 & 3567333 & 3567333 & 3567333 & 3567333 \\
\hline
\end{tabular}

Notes: Robust standard errors clustered by cons. puma in the parentheses. Observations are 60-69 year old civilians in 2010-2018. Includes cons. puma, year, age, age by year, cons. puma by year, age by cons. puma FE, subsidy by cons, puma FE, age by year by subsidy FE, subsidy by cons. puma by age FE, and subsidy by con. puma by year FE. Regressions control for sex, race, ethnicity, and education. Uninsured is demeaned share of 60-64 of cons. puma in 2010-2013 uninsured. Subsidy refers to demeaned average consistent puma level subsidy. Excludes HI and AK.

${ }^{*} p<0.10,{ }^{* *} p<0.05,{ }^{* * *} p<0.01$

\section{Table 11}

Labor Outcomes by Age Group, Uninsured, and Subsidy 60-69

\begin{tabular}{|c|c|c|c|c|c|c|}
\hline & $\begin{array}{c}(1) \\
\text { Not in Labor Force }\end{array}$ & $\begin{array}{c}(2) \\
\text { Employed }\end{array}$ & $\begin{array}{c}(3) \\
\text { Unemployed }\end{array}$ & $\begin{array}{c}\text { (4) } \\
\text { Self Employed }\end{array}$ & $\begin{array}{c}(5) \\
\text { Part-Time }\end{array}$ & $\begin{array}{c}(6) \\
\text { Hours }\end{array}$ \\
\hline Unins x 60-64 x Post & $\begin{array}{l}0.0481^{* *} \\
(0.0225)\end{array}$ & $\begin{array}{l}-0.0235 \\
(0.0223)\end{array}$ & $\begin{array}{c}-0.0246^{* * *} \\
(0.00785)\end{array}$ & $\begin{array}{c}-0.0247^{* *} \\
(0.0126)\end{array}$ & $\begin{array}{c}-0.00944 \\
(0.0124)\end{array}$ & $\begin{array}{c}0.569 \\
(1.101)\end{array}$ \\
\hline Unins x 60-64 x Post x Subsidy $(/ 100)$ & $\begin{array}{l}-0.0413 \\
(0.0255)\end{array}$ & $\begin{array}{l}0.0453^{*} \\
(0.0247)\end{array}$ & $\begin{array}{l}-0.00400 \\
(0.00800)\end{array}$ & $\begin{array}{c}0.0147 \\
(0.0115)\end{array}$ & $\begin{array}{l}-0.00565 \\
(0.0135)\end{array}$ & $\begin{array}{c}1.224 \\
(1.160)\end{array}$ \\
\hline Observations & 3567333 & 3567333 & 3567333 & 3567333 & 3567333 & 1504072 \\
\hline
\end{tabular}


Table A. 1

Illustration of Hypothetical ACA-induced Changes in Labor Market Outcomes

\begin{tabular}{|c|c|c|c|c|c|c|c|}
\hline & \multicolumn{6}{|c|}{ Post-ACA Status } \\
\hline & & $\begin{array}{l}\text { Not in the } \\
\text { Labor Force/ } \\
\text { Uninsured }\end{array}$ & $\begin{array}{l}\text { Employed/ } \\
\text { Uninsured }\end{array}$ & $\begin{array}{l}\text { Unemployed/ } \\
\text { Uninsured }\end{array}$ & $\begin{array}{l}\text { Not in the } \\
\text { Labor Force/ } \\
\text { Insured }\end{array}$ & $\begin{array}{l}\text { Employed/ } \\
\text { Insured }\end{array}$ & $\begin{array}{l}\text { Unemployed/ } \\
\text { Insured }\end{array}$ \\
\hline \multirow{6}{*}{ 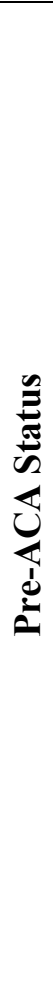 } & $\begin{array}{l}\text { Not in the } \\
\text { Labor Force/ } \\
\text { Uninsured }\end{array}$ & & & & $\begin{array}{l}\text { No Change } \\
\text { in LM } \\
\text { outcomes }\end{array}$ & $\begin{array}{c}\uparrow \text { LFP, } \uparrow \\
\text { Emp, No } \\
\text { change in } \\
\text { Unemp }\end{array}$ & $\begin{array}{c}\uparrow \text { LFP, No } \\
\text { Change in } \\
\text { Emp, } \uparrow \\
\text { Unemp }\end{array}$ \\
\hline & $\begin{array}{l}\text { Employed/ } \\
\text { Uninsured }\end{array}$ & & & & $\begin{array}{c}\downarrow \text { LFP, } \downarrow \\
\text { Emp, No } \\
\text { Change in } \\
\text { Unemp }\end{array}$ & $\begin{array}{c}\text { No Change } \\
\text { in LM } \\
\text { outcomes }\end{array}$ & $\begin{array}{l}\text { No Change } \\
\text { in LFP, } \downarrow \\
\text { Emp, } \\
\uparrow \text { Unemp }\end{array}$ \\
\hline & $\begin{array}{l}\text { Unemployed/ } \\
\text { Uninsured }\end{array}$ & & & & $\begin{array}{l}\downarrow \text { LFP, No } \\
\text { Change in } \\
\text { Emp, } \\
\downarrow \text { Unemp }\end{array}$ & $\begin{array}{c}\text { No Change } \\
\text { in LFP, } \uparrow \\
\text { Emp, } \\
\downarrow \text { Unemp }\end{array}$ & $\begin{array}{l}\text { No Change } \\
\text { in LM } \\
\text { outcomes }\end{array}$ \\
\hline & $\begin{array}{l}\text { Not in the } \\
\text { Labor Force/ } \\
\text { Insured }\end{array}$ & & & & & & \\
\hline & $\begin{array}{l}\text { Employed/ } \\
\text { Insured }\end{array}$ & & & & & & \\
\hline & $\begin{array}{l}\text { Unemployed/ } \\
\text { Insured }\end{array}$ & & & & & & \\
\hline
\end{tabular}




\section{Table A.2}

Insurance Outcomes by Age Group and Uninsured Status, 62-67

\begin{tabular}{|c|c|c|c|c|c|c|}
\hline & $\begin{array}{c}(1) \\
\text { Insured }\end{array}$ & $\begin{array}{c}(2) \\
\text { Num. Cov. }\end{array}$ & $\begin{array}{c}(3) \\
\text { Employer/Union }\end{array}$ & $\begin{array}{c}(4) \\
\text { Direct Purchase }\end{array}$ & $\begin{array}{c}(5) \\
\text { Medicaid }\end{array}$ & $\begin{array}{c}(6) \\
\text { Medicare }\end{array}$ \\
\hline Unins $\times 62-64 \times$ Post & $\begin{array}{l}0.425^{* * *} \\
(0.0245)\end{array}$ & $\begin{array}{l}0.268^{* * *} \\
(0.0480)\end{array}$ & $\begin{array}{l}0.121^{* * *} \\
(0.0328)\end{array}$ & $\begin{array}{l}0.101^{* * *} \\
(0.0263)\end{array}$ & $\begin{array}{l}0.0822^{* *} \\
(0.0334)\end{array}$ & $\begin{array}{l}-0.0271 \\
(0.0230)\end{array}$ \\
\hline Obs. & 2173903 & 2173903 & 2173903 & 2173903 & 2173903 & 2173903 \\
\hline Mean Dep. Var & 0.882 & 1.082 & 0.595 & 0.152 & 0.0972 & 0.133 \\
\hline SD Dep. Var & 0.323 & 0.631 & 0.491 & 0.359 & 0.296 & 0.339 \\
\hline
\end{tabular}

Notes: Robust standard errors clustered by consistent puma in the parentheses. Observations are 62-67 year old civilians in 2010-2018 from IPUMS-ACS. Includes cons. puma, year, age, age by year, cons. puma by year, and age by cons. puma FE.

Regressions control for sex, race, ethnicity, and education. Uninsured is demeaned share of 62-64 of cons. puma in 2010-2013 uninsured. ${ }^{*} p<0.10,{ }^{* *} p<0.05,{ }^{* * *} p<0.01$

\section{Table A.3}

Insurance Outcomes by Age Group, Uninsured, and Expan Status 62-67

\begin{tabular}{|c|c|c|c|c|c|c|}
\hline & $\begin{array}{c}(1) \\
\text { Insured }\end{array}$ & $\begin{array}{c}(2) \\
\text { Num. Cov. }\end{array}$ & $\begin{array}{c}(3) \\
\text { Employer/Union }\end{array}$ & $\begin{array}{c}(4) \\
\text { Direct Purchase }\end{array}$ & $\begin{array}{c}(5) \\
\text { Medicaid }\end{array}$ & $\begin{array}{c}(6) \\
\text { Medicare }\end{array}$ \\
\hline Unins $\mathrm{x}$ 62-64 x Post & $\begin{array}{l}0.317^{* * *} \\
(0.0320)\end{array}$ & $\begin{array}{l}0.201^{* * *} \\
(0.0742)\end{array}$ & $\begin{array}{l}0.116^{* *} \\
(0.0517)\end{array}$ & $\begin{array}{l}0.103^{* * *} \\
(0.0392)\end{array}$ & $\begin{array}{l}-0.0227 \\
(0.0271)\end{array}$ & $\begin{array}{l}-0.0209 \\
(0.0331)\end{array}$ \\
\hline Unins $x$ 62-64 x Post $x$ Expan & $\begin{array}{l}0.252^{* * *} \\
(0.0394)\end{array}$ & $\begin{array}{c}0.163^{*} \\
(0.0943)\end{array}$ & $\begin{array}{l}-0.00502 \\
(0.0658)\end{array}$ & $\begin{array}{l}-0.0361 \\
(0.0501)\end{array}$ & $\begin{array}{l}0.272^{* * *} \\
(0.0466)\end{array}$ & $\begin{array}{l}-0.0193 \\
(0.0459)\end{array}$ \\
\hline Obs. & 2173903 & 2173903 & 2173903 & 2173903 & 2173903 & 2173903 \\
\hline Mean Dep. Var (Ex) & 0.891 & 1.074 & 0.610 & 0.149 & 0.105 & 0.122 \\
\hline SD Dep. Var (Ex) & 0.312 & 0.602 & 0.488 & 0.357 & 0.307 & 0.327 \\
\hline Mean Dep. Var (Non-Ex) & 0.873 & 1.089 & 0.581 & 0.154 & 0.0893 & 0.143 \\
\hline SD Dep. Var (Non-Ex) & 0.333 & 0.660 & 0.493 & 0.361 & 0.285 & 0.350 \\
\hline
\end{tabular}

Note: Robust standard errors in parentheses clustered by consistent puma. Observations are 62-67 year old civilians in 2010-2018. Expan refers to states that expanded Medicaid in 2014. Includes cons. puma, year, age, age by year, cons. puma by year, age by cons. puma FE, and age by year by expansion status FE. Regressions control for sex, race, ethnicity, and education. Uninsured is demeaned share of 62-64 of of cons. puma in 2010-2013 uninsured.

${ }^{*} p<0.10,{ }^{* *} p<0.05,{ }^{* * *} p<0.01$ 


\section{Table A.4}

Insurance Coverage by Age Group and Uninsured Status (Het.), 62-67

\begin{tabular}{lcccccccc}
\hline & $(1)$ & $(2)$ & $(3)$ & $(4)$ & $(5)$ & $(6)$ & $(7)$ & $(8)$ \\
& Non-Minority & Minority & HSG or Less & College & Male & Female & $\begin{array}{c}(7) \\
\text { Non-married }\end{array}$ & \begin{tabular}{c} 
Married \\
\hline Unins x 62-64 x Post
\end{tabular} \\
& $0.284^{* * *}$ & $0.484^{* * *}$ & $0.504^{* * *}$ & $0.302^{* * *}$ & $0.366^{* * *}$ & $0.466^{* * *}$ & $0.409^{* * *}$ & $0.412^{* * *}$ \\
& $(0.0253)$ & $(0.0469)$ & $(0.0378)$ & $(0.0212)$ & $(0.0306)$ & $(0.0313)$ & $(0.0408)$ & $(0.0245)$ \\
\hline Obs. & 1694371 & 479235 & 1031109 & 1142794 & 1032003 & 1141900 & 686450 & 1487453 \\
Mean Dep. Var & 0.909 & 0.796 & 0.838 & 0.921 & 0.893 & 0.872 & 0.830 & 0.907 \\
SD Dep. Var & 0.287 & 0.403 & 0.368 & 0.270 & 0.310 & 0.334 & 0.375 & 0.291 \\
\hline
\end{tabular}

Notes: Robust standard errors clustered by consistent puma in the parentheses. Observations are 62-67 year old civilians

in 2010-2018 from IPUMS-ACS. Includes cons. puma, year, age, age by year, cons. puma by year, and age by cons. puma FE.

Regressions control for sex, race, ethnicity, and education. Uninsured is demeaned share of 62-64 of cons. puma in 2010-2013 uninsured.

Non-minority refers to white, non-hispanic. Married includes separated.

${ }^{*} p<0.10,{ }^{* *} p<0.05,{ }^{* * *} p<0.01$

\section{Table A.5}

Insurance Coverage by Age Group, Uninsured and Expan Status (Het.), 62-67

\begin{tabular}{lcccccccc}
\hline & $(1)$ & $(2)$ & $(3)$ & $(4)$ & $(5)$ & $(6)$ & $(7)$ & $(8)$ \\
& Non-Minority & Minority & HSG or Less & College & Male & Female & Non-married & Married \\
\hline Unins x 62-64 x Post & $0.217^{* * *}$ & $0.326^{* * *}$ & $0.356^{* * *}$ & $0.243^{* * *}$ & $0.272^{* * *}$ & $0.348^{* * *}$ & $0.263^{* * *}$ & $0.333^{* * *}$ \\
& $(0.0352)$ & $(0.0720)$ & $(0.0478)$ & $(0.0304)$ & $(0.0522)$ & $(0.0351)$ & $(0.0568)$ & $(0.0342)$ \\
Unins x 62-64 x Post x Expan & $0.185^{* * *}$ & $0.338^{* * *}$ & $0.344^{* * *}$ & $0.151^{* * *}$ & $0.231^{* * *}$ & $0.269^{* * *}$ & $0.330^{* * *}$ & $0.188^{* * *}$ \\
& $(0.0454)$ & $(0.0858)$ & $(0.0605)$ & $(0.0400)$ & $(0.0604)$ & $(0.0483)$ & $(0.0723)$ & $(0.0446)$ \\
\hline Obs. & 1694371 & 479235 & 1031109 & 1142794 & 1032003 & 1141900 & 686450 & 1487453 \\
Mean Dep. Var (Ex) & 0.919 & 0.811 & 0.848 & 0.926 & 0.899 & 0.883 & 0.846 & 0.913 \\
SD Dep. Var (Ex) & 0.274 & 0.391 & 0.359 & 0.262 & 0.302 & 0.321 & 0.361 & 0.282 \\
Mean Dep. Var (Non-Ex) & 0.901 & 0.778 & 0.830 & 0.915 & 0.886 & 0.861 & 0.814 & 0.901 \\
SD Dep. Var (Non-Ex) & 0.299 & 0.416 & 0.375 & 0.278 & 0.317 & 0.346 & 0.389 & 0.299 \\
\hline
\end{tabular}

Note: Robust standard errors in parentheses clustered by consistent puma. Observations are 62-67 year old civilians in 2010-2018. Expan refers to states that expanded Medicaid in 2014. Includes cons. puma, year, age, age by year, cons. puma by year, age by cons. puma $\mathrm{FE}$, and age by year by expansion status FE. Regressions control for sex, race, ethnicity, and education. Uninsured is demeaned share of 62-64 of

of cons. puma in 2010-2013 uninsured. Non-minority refers to white, non-Hispanic. Married includes separated.

${ }^{*} p<0.10,{ }^{*} p<0.05, \cdots p<0.01$ 


\section{Table A.6}

Labor Outcomes by Age Group and Uninsured Status, 62-67

\begin{tabular}{lcccccc}
\hline & $(1)$ & $(2)$ & $(3)$ & $(4)$ & $(5)$ & $(6)$ \\
& Not in Labor Force & Employed & Unemployed & Self Employed & Part-Time & Hours \\
\hline Unins x 62-64 x Post & $0.0589^{*}$ & -0.0466 & -0.0123 & $-0.0507^{* * *}$ & -0.0154 & -0.0408 \\
& $(0.0326)$ & $(0.0319)$ & $(0.00874)$ & $(0.0164)$ & $(0.0157)$ & $(1.294)$ \\
\hline Obs. & 2173903 & 2173903 & 2173903 & 2173903 & 2173903 & 882512 \\
Mean Dep. Var & 0.507 & 0.459 & 0.0337 & 0.0733 & 0.0824 & 38.20 \\
SD Dep. Var & 0.500 & 0.498 & 0.180 & 0.261 & 0.275 & 12.87 \\
\hline
\end{tabular}

Notes: Robust standard errors clustered by consistent puma in the parentheses. Observations are 62-67 year old civilians in 2010-2018 from IPUMS-ACS. Includes cons. puma, year, age, age by year, cons. puma by year, and age by cons. puma FE.

Regressions control for sex, race, ethnicity, and education. Uninsured is demeaned share of 62-64 of cons. puma in 2010-2013 uninsured.

${ }^{*} p<0.10,{ }^{* *} p<0.05,{ }^{* * *} p<0.01$

Table A.7

Labor Outcomes by Age Group, Uninsured, and Expan Status 62-67

\begin{tabular}{lcccccc}
\hline & $(1)$ & $(2)$ & $(3)$ & $(4)$ & $(5)$ & $(6)$ \\
& Not in Labor Force & Employed & Unemployed & Self Employed & Part-Time & Hours \\
\hline Unins x 62-64 x Post & 0.0852 & -0.0768 & -0.00840 & $-0.0603^{* *}$ & -0.00655 & 0.834 \\
& $(0.0544)$ & $(0.0531)$ & $(0.0134)$ & $(0.0249)$ & $(0.0226)$ & $(2.021)$ \\
Unins x 62-64 x Post x Expan & -0.0432 & 0.0490 & -0.00580 & 0.0213 & -0.0169 & -0.853 \\
& $(0.0656)$ & $(0.0640)$ & $(0.0181)$ & $(0.0325)$ & $(0.0320)$ & $(2.627)$ \\
\hline Obs. & 2173903 & 2173903 & 2173903 & 2173903 & 2173903 & 882512 \\
Mean Dep. Var (Ex) & 0.491 & 0.473 & 0.0366 & 0.0772 & 0.0861 & 37.93 \\
SD Dep. Var (Ex) & 0.500 & 0.499 & 0.188 & 0.267 & 0.281 & 12.79 \\
Mean Dep. Var (Non-Ex) & 0.524 & 0.446 & 0.0307 & 0.0695 & 0.0788 & 38.49 \\
SD Dep. Var (Non-Ex) & 0.499 & 0.497 & 0.173 & 0.254 & 0.269 & 12.95 \\
\hline
\end{tabular}

Note: Robust standard errors in parentheses clustered by consistent puma. Observations are 62-67 year old civilians in 2010-2018. Expan refers to states that expanded Medicaid in 2014. Includes cons. puma, year, age, age by year, cons. puma by year, age by cons. puma FE, and age by year by expansion status FE. Regressions control for sex, race, ethnicity, and education. Uninsured is demeaned share of $62-64$ of of cons. puma in 2010-2013 uninsured.

${ }^{*} p<0.10,{ }^{* *} p<0.05,{ }^{* * *} p<0.01$ 


\section{Table A.8}

Not in the Labor Force by Age Group and Uninsured Status (Het.), 62-67

\begin{tabular}{lcccccccc}
\hline & $(1)$ & $(2)$ & $(3)$ & $(4)$ & $(5)$ & $(6)$ & $(7)$ & $(8)$ \\
& Non-Minority & Minority & HSG or Less & College & Male & Female & Non-married & Married \\
\hline Unins x 62-64 x Post & 0.0158 & 0.0471 & $0.122^{* *}$ & -0.0183 & 0.0744 & 0.0462 & 0.0150 & $0.0704^{*}$ \\
& $(0.0378)$ & $(0.0603)$ & $(0.0491)$ & $(0.0419)$ & $(0.0532)$ & $(0.0391)$ & $(0.0507)$ & $(0.0395)$ \\
\hline Obs. & 1694371 & 479235 & 1031109 & 1142794 & 1032003 & 1141900 & 686450 & 1487453 \\
Mean Dep. Var & 0.495 & 0.546 & 0.586 & 0.437 & 0.462 & 0.549 & 0.531 & 0.496 \\
SD Dep. Var & 0.500 & 0.498 & 0.493 & 0.496 & 0.499 & 0.498 & 0.499 & 0.500 \\
\hline
\end{tabular}

Notes: Robust standard errors clustered by consistent puma in the parentheses. Observations are 62-67 year old civilians

in 2010-2018 from IPUMS-ACS. Includes cons. puma, year, age, age by year, cons. puma by year, and age by cons. puma FE.

Regressions control for sex, race, ethnicity, and education. Uninsured is demeaned share of 62-64 of cons. puma in 2010-2013 uninsured.

Non-minority refers to white, non-Hispanic. Married includes separated.

${ }^{*} p<0.10,{ }^{* *} p<0.05,{ }^{* * *} p<0.01$

\section{Table A.9}

Not in the Labor Force by Age Group, Uninsured and Expan Status (Het.), 62-67

\begin{tabular}{|c|c|c|c|c|c|c|c|c|}
\hline & $\begin{array}{c}(1) \\
\text { Non-Minority }\end{array}$ & $\begin{array}{c}(2) \\
\text { Minority }\end{array}$ & $\begin{array}{c}(3) \\
\text { HSG or Less }\end{array}$ & $\begin{array}{c}(4) \\
\text { College }\end{array}$ & $\begin{array}{c}(5) \\
\text { Male }\end{array}$ & $\begin{array}{c}(6) \\
\text { Female }\end{array}$ & $\begin{array}{c}(7) \\
\text { Non-married }\end{array}$ & $\begin{array}{c}(8) \\
\text { Married }\end{array}$ \\
\hline Unins $\mathrm{x} 62-64 \mathrm{x}$ Post & $\begin{array}{l}-0.0216 \\
(0.0588)\end{array}$ & $\begin{array}{c}0.154^{*} \\
(0.0915)\end{array}$ & $\begin{array}{c}0.111 \\
(0.0856)\end{array}$ & $\begin{array}{c}0.0601 \\
(0.0624)\end{array}$ & $\begin{array}{c}0.0856 \\
(0.0918)\end{array}$ & $\begin{array}{c}0.0948^{*} \\
(0.0517)\end{array}$ & $\begin{array}{c}0.0194 \\
(0.0765)\end{array}$ & $\begin{array}{c}0.106^{*} \\
(0.0640)\end{array}$ \\
\hline Unins x 62-64 x Post x Expan & $\begin{array}{c}0.0763 \\
(0.0785)\end{array}$ & $\begin{array}{l}-0.199^{*} \\
(0.108)\end{array}$ & $\begin{array}{l}0.0174 \\
(0.101)\end{array}$ & $\begin{array}{c}-0.132 \\
(0.0867)\end{array}$ & $\begin{array}{c}-0.0314 \\
(0.109)\end{array}$ & $\begin{array}{c}-0.0691 \\
(0.0770)\end{array}$ & $\begin{array}{c}-0.0164 \\
(0.105)\end{array}$ & $\begin{array}{l}-0.0520 \\
(0.0788)\end{array}$ \\
\hline Obs. & 1694371 & 479235 & 1031109 & 1142794 & 1032003 & 1141900 & 686450 & 1487453 \\
\hline Mean Dep. Var (Ex) & 0.479 & 0.524 & 0.573 & 0.423 & 0.448 & 0.530 & 0.514 & 0.479 \\
\hline SD Dep. Var (Ex) & 0.500 & 0.499 & 0.495 & 0.494 & 0.497 & 0.499 & 0.500 & 0.500 \\
\hline Mean Dep. Var (Non-Ex) & 0.510 & 0.572 & 0.597 & 0.451 & 0.476 & 0.567 & 0.548 & 0.512 \\
\hline SD Dep. Var (Non-Ex) & 0.500 & 0.495 & 0.491 & 0.498 & 0.499 & 0.495 & 0.498 & 0.500 \\
\hline
\end{tabular}

Note: Robust standard errors in parentheses clustered by consistent puma. Observations are 62-67 year old civilians in 2010-2018. Expan refers to states that expanded Medicaid in 2014. Includes cons. puma, year, age, age by year, cons. puma by year, age by cons. puma FE, and age by year by expansion status FE. Regressions control for sex, race, ethnicity, and education. Uninsured is demeaned share of 62-64 of

of cons. puma in 2010-2013 uninsured. Non-minority refers to white, non-Hispanic. Married includes separated.

${ }^{*} p<0.10,{ }^{* *} p<0.05,{ }^{* *} p<0.01$ 


\section{Table A.10}

Insurance Outcomes by Age Group and Uninsured Status, 55-64

\begin{tabular}{lcccccc}
\hline & $(1)$ & $(2)$ & $(3)$ & $(4)$ & $(5)$ & $(6)$ \\
& Insured & Num. Cov. & Employer/Union & Direct Purchase & Medicaid & Medicare \\
\hline Unins x 55-59 x Post & $0.0681^{* * *}$ & $0.0587^{*}$ & $0.0393^{* *}$ & 0.0187 & 0.0125 & -0.00702 \\
& $(0.0192)$ & $(0.0303)$ & $(0.0191)$ & $(0.0124)$ & $(0.0167)$ & $(0.0118)$ \\
\hline Obs. & 4042914 & 4042914 & 4042914 & 4042914 & 4042914 & 4042914 \\
Mean Dep. Var & 0.857 & 0.979 & 0.643 & 0.115 & 0.0986 & 0.0726 \\
SD Dep. Var & 0.350 & 0.553 & 0.479 & 0.319 & 0.298 & 0.260 \\
\hline
\end{tabular}

Notes: Robust standard errors clustered by consistent puma in the parentheses. Observations are 55-64 year old civilians in 2010-2018 from IPUMS-ACS. Includes cons. puma, year, age, age by year, cons. puma by year, and age by cons. puma FE.

Regressions control for sex, race, ethnicity, and education. Uninsured is demeaned share of 55-59 of cons. puma in 2010-2013 uninsured. ${ }^{*} p<0.10,{ }^{* *} p<0.05,{ }^{* * *} p<0.01$

Table A.11

Insurance Outcomes by Age Group, Uninsured, and Expan Status 55-64

\begin{tabular}{|c|c|c|c|c|c|c|}
\hline & $\begin{array}{c}(1) \\
\text { Insured }\end{array}$ & $\begin{array}{c}\text { (2) } \\
\text { Num. Cov. }\end{array}$ & $\begin{array}{c}(3) \\
\text { Employer/Union }\end{array}$ & $\begin{array}{c}(4) \\
\text { Direct Purchase }\end{array}$ & $\begin{array}{c}(5) \\
\text { Medicaid }\end{array}$ & $\begin{array}{c}(6) \\
\text { Medicare }\end{array}$ \\
\hline Unins x 55-59 x Post & $\begin{array}{l}0.0624^{*} \\
(0.0328)\end{array}$ & $\begin{array}{c}0.0632 \\
(0.0543)\end{array}$ & $\begin{array}{c}0.0456 \\
(0.0305)\end{array}$ & $\begin{array}{l}0.0302^{*} \\
(0.0166)\end{array}$ & $\begin{array}{l}-0.00867 \\
(0.0237)\end{array}$ & $\begin{array}{c}0.0156 \\
(0.0175)\end{array}$ \\
\hline Unins x 55-59 x Post $x$ Expan & $\begin{array}{c}0.0238 \\
(0.0387)\end{array}$ & $\begin{array}{l}-0.00614 \\
(0.0624)\end{array}$ & $\begin{array}{r}-0.00778 \\
(0.0396)\end{array}$ & $\begin{array}{l}-0.00538 \\
(0.0242)\end{array}$ & $\begin{array}{c}0.0453 \\
(0.0334)\end{array}$ & $\begin{array}{l}-0.0433^{*} \\
(0.0243)\end{array}$ \\
\hline Obs. & 4042914 & 4042914 & 4042914 & 4042914 & 4042914 & 4042914 \\
\hline Mean Dep. Var (Ex) & 0.869 & 0.980 & 0.655 & 0.114 & 0.107 & 0.0647 \\
\hline SD Dep. Var (Ex) & 0.337 & 0.527 & 0.475 & 0.318 & 0.309 & 0.246 \\
\hline Mean Dep. Var (Non-Ex) & 0.845 & 0.977 & 0.631 & 0.115 & 0.0905 & 0.0806 \\
\hline SD Dep. Var (Non-Ex) & 0.362 & 0.578 & 0.483 & 0.320 & 0.287 & 0.272 \\
\hline
\end{tabular}




\section{Table A.12}

Insurance Coverage by Age Group and Uninsured Status (Het.), 55-64

\begin{tabular}{lcccccccc}
\hline & $\begin{array}{c}(1) \\
\text { Non-Minority }\end{array}$ & $\begin{array}{c}(2) \\
\text { Minority }\end{array}$ & $\begin{array}{c}(3) \\
\text { HSG or Less }\end{array}$ & $\begin{array}{c}(4) \\
\text { College }\end{array}$ & $\begin{array}{c}(5) \\
\text { Male }\end{array}$ & $\begin{array}{c}(6) \\
\text { Female }\end{array}$ & $\begin{array}{c}(7) \\
\text { Non-married }\end{array}$ & $\begin{array}{c}(8) \\
\text { Married }\end{array}$ \\
\hline Unins x 55-59 x Post & $0.0821^{* * *}$ & 0.0313 & $0.0449^{*}$ & $0.0841^{* * *}$ & $0.101^{* * *}$ & $0.0415^{* *}$ & $0.0759^{* *}$ & $0.0590^{* * *}$ \\
& $(0.0160)$ & $(0.0319)$ & $(0.0271)$ & $(0.0186)$ & $(0.0256)$ & $(0.0196)$ & $(0.0320)$ & $(0.0189)$ \\
\hline Obs. & 3061128 & 981714 & 1920660 & 2122254 & 1937328 & 2105586 & 1270495 & 2772419 \\
Mean Dep. Var & 0.891 & 0.766 & 0.802 & 0.907 & 0.851 & 0.862 & 0.791 & 0.890 \\
SD Dep. Var & 0.312 & 0.423 & 0.399 & 0.290 & 0.356 & 0.345 & 0.407 & 0.313 \\
\hline
\end{tabular}

Notes: Robust standard errors clustered by consistent puma in the parentheses. Observations are 55-64 year old civilians

in 2010-2018 from IPUMS-ACS. Includes cons. puma, year, age, age by year, cons. puma by year, and age by cons. puma FE.

Regressions control for sex, race, ethnicity, and education. Uninsured is demeaned share of 55-59 of cons. puma in 2010-2013 uninsured.

Non-minority refers to white, non-Hispanic. Married includes separated.

${ }^{*} p<0.10,{ }^{* *} p<0.05,{ }^{* * *} p<0.01$

\section{Table A.13}

Insurance Coverage by Age Group, Uninsured and Expan Status (Het.), 55-64

\begin{tabular}{lcccccccc}
\hline & $(1)$ & $(2)$ & $(3)$ & $(4)$ & $(5)$ & $(6)$ & $(7)$ & $(8)$ \\
& Non-Minority & Minority & HSG or Less & College & Male & Female & Non-married & Married \\
\hline Unins x 55-59 x Post & $0.0707^{* * *}$ & 0.0333 & 0.0439 & $0.0816^{* *}$ & $0.0994^{* *}$ & 0.0351 & 0.0649 & $0.0527^{*}$ \\
& $(0.0260)$ & $(0.0554)$ & $(0.0438)$ & $(0.0318)$ & $(0.0418)$ & $(0.0320)$ & $(0.0560)$ & $(0.0319)$ \\
Unins x 55-59 x Post x Expan & 0.0413 & 0.00305 & 0.0123 & 0.0177 & 0.0172 & 0.0262 & 0.0491 & 0.0154 \\
& $(0.0326)$ & $(0.0655)$ & $(0.0544)$ & $(0.0387)$ & $(0.0521)$ & $(0.0397)$ & $(0.0655)$ & $(0.0385)$ \\
\hline Obs. & 3061128 & 981714 & 1920660 & 2122254 & 1937328 & 2105586 & 1270495 & 2772419 \\
Mean Dep. Var (Ex) & 0.904 & 0.783 & 0.814 & 0.914 & 0.862 & 0.875 & 0.812 & 0.898 \\
SD Dep. Var (Ex) & 0.294 & 0.412 & 0.389 & 0.280 & 0.344 & 0.331 & 0.391 & 0.303 \\
Mean Dep. Var (Non-Ex) & 0.878 & 0.747 & 0.790 & 0.899 & 0.840 & 0.850 & 0.769 & 0.882 \\
SD Dep. Var (Non-Ex) & 0.327 & 0.435 & 0.407 & 0.301 & 0.367 & 0.357 & 0.422 & 0.323 \\
\hline
\end{tabular}

Note: Robust standard errors in parentheses clustered by consistent puma. Observations are 55-64 year old civilians in 2010-2018. Expan refers to states that expanded Medicaid in 2014. Includes cons. puma, year, age, age by year, cons. puma by year, age by cons. puma $\mathrm{FE}$, and age by year by expansion status FE. Regressions control for sex, race, ethnicity, and education. Uninsured is demeaned share of 55-59 of

of cons. puma in 2010-2013 uninsured. Non-minority refers to white, non-Hispanic. Married includes separated.

${ }^{*} p<0.10,{ }^{* *} p<0.05,{ }^{* * *} p<0.01$ 


\section{Table A.14}

Labor Outcomes by Age Group and Uninsured Status, 55-64

\begin{tabular}{lcccccc}
\hline & $(1)$ & $(2)$ & $(3)$ & $(4)$ & $(5)$ & $(6)$ \\
& Not in Labor Force & Employed & Unemployed & Self Employed & Part-Time & Hours \\
\hline Unins x 55-59 x Post & -0.0253 & $0.0391^{* *}$ & -0.0138 & 0.00118 & -0.0142 & 0.537 \\
& $(0.0189)$ & $(0.0189)$ & $(0.00877)$ & $(0.0115)$ & $(0.0109)$ & $(0.598)$ \\
\hline Obs. & 4042914 & 4042914 & 4042914 & 4042914 & 4042914 & 2459513 \\
Mean Dep. Var & 0.277 & 0.672 & 0.0507 & 0.0895 & 0.0706 & 40.61 \\
SD Dep. Var & 0.448 & 0.469 & 0.219 & 0.285 & 0.256 & 11.47 \\
\hline
\end{tabular}

Notes: Robust standard errors clustered by consistent puma in the parentheses. Observations are 55-64 year old civilians in 2010-2018 from IPUMS-ACS. Includes cons. puma, year, age, age by year, cons. puma by year, and age by cons. puma FE.

Regressions control for sex, race, ethnicity, and education. Uninsured is demeaned share of 55-59 of cons. puma in 2010-2013 uninsured. ${ }^{*} p<0.10,{ }^{* *} p<0.05,{ }^{* * *} p<0.01$

\section{Table A.15}

Labor Outcomes by Age Group, Uninsured, and Expan Status 55-64

\begin{tabular}{|c|c|c|c|c|c|c|}
\hline & Not in Labor Force & $\begin{array}{c}(2) \\
\text { Employed }\end{array}$ & $\begin{array}{c}(3) \\
\text { Unemployed }\end{array}$ & $\begin{array}{c}(4) \\
\text { Self Employed }\end{array}$ & $\begin{array}{c}\text { (5) } \\
\text { Part-Time }\end{array}$ & $\begin{array}{c}(6) \\
\text { Hours }\end{array}$ \\
\hline Unins x 55-59 x Post & $\begin{array}{l}-0.0267 \\
(0.0302)\end{array}$ & $\begin{array}{l}0.0506^{*} \\
(0.0305)\end{array}$ & $\begin{array}{c}-0.0240^{* *} \\
(0.0118)\end{array}$ & $\begin{array}{l}0.00543 \\
(0.0173)\end{array}$ & $\begin{array}{l}0.00399 \\
(0.0158)\end{array}$ & $\begin{array}{l}-0.541 \\
(0.816)\end{array}$ \\
\hline Unins x 55-59 x Post x Expan & $\begin{array}{r}-0.00959 \\
(0.0390)\end{array}$ & $\begin{array}{l}-0.0121 \\
(0.0392)\end{array}$ & $\begin{array}{c}0.0217 \\
(0.0177)\end{array}$ & $\begin{array}{l}-0.0123 \\
(0.0231)\end{array}$ & $\begin{array}{l}-0.0337 \\
(0.0218)\end{array}$ & $\begin{array}{c}1.830 \\
(1.178)\end{array}$ \\
\hline Obs. & 4042914 & 4042914 & 4042914 & 4042914 & 4042914 & 2459513 \\
\hline Mean Dep. Var (Ex) & 0.266 & 0.680 & 0.0536 & 0.0933 & 0.0754 & 40.28 \\
\hline SD Dep. Var (Ex) & 0.442 & 0.466 & 0.225 & 0.291 & 0.264 & 11.49 \\
\hline Mean Dep. Var (Non-Ex) & 0.288 & 0.664 & 0.0479 & 0.0857 & 0.0658 & 40.95 \\
\hline SD Dep. Var (Non-Ex) & 0.453 & 0.472 & 0.213 & 0.280 & 0.248 & 11.44 \\
\hline \multicolumn{7}{|c|}{$\begin{array}{l}\text { Note: Robust standard errors in parentheses clustered by consistent puma. Observations are } 55-64 \text { year old civilians in } 2010-2018 \text {. Expan refers to } \\
\text { states that expanded Medicaid in } 2014 \text {. Includes cons. puma, year, age, age by year, cons. puma by year, age by cons. puma FE, and age by year } \\
\text { by expansion status FE. Regressions control for sex, race, ethnicity, and education. Uninsured is demeaned share of } 55-59 \text { of } \\
\text { of cons. puma in } 2010-2013 \text { uninsured. } \\
{ }^{*} p<0.10,{ }^{* *} p<0.05,{ }^{* * *} p<0.01\end{array}$} \\
\hline
\end{tabular}




\section{Table A.16}

Not in the Labor Force by Age Group and Uninsured Status (Het.), 55-64

\begin{tabular}{lcccccccc}
\hline & $(1)$ & $(2)$ & $(3)$ & $(4)$ & $(5)$ & $(6)$ & $(7)$ & $(8)$ \\
& Non-Minority & Minority & HSG or Less & College & Male & Female & Non-married & Married \\
\hline Unins x 55-59 x Post & -0.00239 & -0.00692 & -0.00706 & $-0.0458^{*}$ & $-0.0532^{* *}$ & -0.000494 & -0.00410 & -0.0248 \\
& $(0.0268)$ & $(0.0279)$ & $(0.0270)$ & $(0.0256)$ & $(0.0248)$ & $(0.0281)$ & $(0.0324)$ & $(0.0232)$ \\
\hline Obs. & 3061128 & 981714 & 1920660 & 2122254 & 1937328 & 2105586 & 1270495 & 2772419 \\
Mean Dep. Var & 0.259 & 0.325 & 0.352 & 0.209 & 0.228 & 0.324 & 0.332 & 0.250 \\
SD Dep. Var & 0.438 & 0.468 & 0.478 & 0.407 & 0.419 & 0.468 & 0.471 & 0.433 \\
\hline
\end{tabular}

Notes: Robust standard errors clustered by consistent puma in the parentheses. Observations are 55-64 year old civilians in 2010-2018 from IPUMS-ACS. Includes cons. puma, year, age, age by year, cons. puma by year, and age by cons. puma FE.

Regressions control for sex, race, ethnicity, and education. Uninsured is demeaned share of 55-59 of cons. puma in 2010-2013 uninsured.

Non-minority refers to white, non-Hispanic. Married includes separated.

${ }^{*} p<0.10,{ }^{* *} p<0.05,{ }^{* * *} p<0.01$

Table A.17

Not in the Labor Force by Age Group, Uninsured and Expan Status (Het.), 55-64

\begin{tabular}{|c|c|c|c|c|c|c|c|c|}
\hline & $\begin{array}{c}(1) \\
\text { Non-Minority }\end{array}$ & $\begin{array}{c}(2) \\
\text { Minority }\end{array}$ & $\begin{array}{c}(3) \\
\text { HSG or Less }\end{array}$ & $\begin{array}{c}(4) \\
\text { College }\end{array}$ & $\begin{array}{c}(5) \\
\text { Male }\end{array}$ & $\begin{array}{c}(6) \\
\text { Female }\end{array}$ & $\begin{array}{c}(7) \\
\text { Non-married }\end{array}$ & $\begin{array}{c}(8) \\
\text { Married }\end{array}$ \\
\hline Unins $\mathrm{x} 55-59 \mathrm{x}$ Post & $\begin{array}{l}-0.0252 \\
(0.0459)\end{array}$ & $\begin{array}{l}0.00791 \\
(0.0425)\end{array}$ & $\begin{array}{c}0.0205 \\
(0.0447)\end{array}$ & $\begin{array}{c}-0.0817^{* *} \\
(0.0389)\end{array}$ & $\begin{array}{l}-0.0517 \\
(0.0397)\end{array}$ & $\begin{array}{c}-0.00413 \\
(0.0444)\end{array}$ & $\begin{array}{c}0.0134 \\
(0.0540)\end{array}$ & $\begin{array}{c}-0.0314 \\
(0.0360)\end{array}$ \\
\hline Unins $\mathrm{x} 55-59 \times$ Post $\mathrm{x}$ Expan & $\begin{array}{c}0.0377 \\
(0.0559)\end{array}$ & $\begin{array}{l}-0.0449 \\
(0.0586)\end{array}$ & $\begin{array}{l}-0.0624 \\
(0.0562)\end{array}$ & $\begin{array}{c}0.0534 \\
(0.0546)\end{array}$ & $\begin{array}{r}-0.00169 \\
(0.0516)\end{array}$ & $\begin{array}{l}-0.0163 \\
(0.0571)\end{array}$ & $\begin{array}{l}-0.0382 \\
(0.0685)\end{array}$ & $\begin{array}{r}-0.00147 \\
(0.0473)\end{array}$ \\
\hline Obs. & 3061128 & 981714 & 1920660 & 2122254 & 1937328 & 2105586 & 1270495 & 2772419 \\
\hline Mean Dep. Var (Ex) & 0.248 & 0.309 & 0.343 & 0.203 & 0.218 & 0.311 & 0.318 & 0.240 \\
\hline SD Dep. Var (Ex) & 0.432 & 0.462 & 0.475 & 0.402 & 0.413 & 0.463 & 0.466 & 0.427 \\
\hline Mean Dep. Var (Non-Ex) & 0.269 & 0.343 & 0.360 & 0.217 & 0.238 & 0.336 & 0.346 & 0.260 \\
\hline SD Dep. Var (Non-Ex) & 0.444 & 0.475 & 0.480 & 0.412 & 0.426 & 0.472 & 0.476 & 0.439 \\
\hline
\end{tabular}

Note: Robust standard errors in parentheses clustered by consistent puma. Observations are 55-64 year old civilians in 2010-2018. Expan refers to states that expanded Medicaid in 2014. Includes cons. puma, year, age, age by year, cons. puma by year, age by cons. puma FE, and age by year by expansion status FE. Regressions control for sex, race, ethnicity, and education. Uninsured is demeaned share of 55-59 of

of cons. puma in 2010-2013 uninsured. Non-minority refers to white, non-Hispanic. Married includes separated.

${ }^{*} p<0.10,{ }^{* *} p<0.05,{ }^{* * *} p<0.01$ 